Boise State University

ScholarWorks

$1-22-2014$

\title{
Morphologic and Molecular Description of Metopus fuscus Kahl from North America and New rDNA Sequences from Seven Metopids (Armophorea, Metopidae)
}

\author{
William A. Bourland \\ Boise State University \\ Laura Wendell \\ Boise State University \\ Greg Hampikian \\ Boise State University
}




\section{Morphologic and molecular description of Metopus fuscus Kahl from North}

\section{America and new rDNA sequences from seven metopids (Armophorea,}

\section{Metopidae)}

William A. Bourland*, Laura Wendell, Greg Hampikian

Boise State University, Department of Biological Sciences, Boise, Idaho 83725-1515, USA

Number of pages: 37

Number of Tables: 2

Number of Figures: 64 on 8 plates

* Corresponding author. Tel.: +1 208861 4449; fax: +1 8153018958.

E-mail address:willbour@me.com 


\begin{abstract}
Most species in the large ciliate genus Metopus Claparède \& Lachmann, 1858 lack detailed descriptions based on modern morphologic and molecular methods. This lack of data for the vast majority of species hampers application of a morphospecies approach to the taxonomy of Metopus and other armophorids. In this report we redescribe the large species, Metopus fuscus Kahl, 1927 based on in vivo observation, silver impregnation, scanning electron microscopy, and single-cell 18S rDNA sequencing of a freshwater North American (Idaho) population. Metopus fuscus invariably has a perinuclear envelope of endosymbiotic bacteria not found in other species. Unlike the original description of a single row of coarse granules between ciliary rows, the Idaho population has five loose rows of small interkinetal granules. We discuss the possible importance of this character in metopids. We also provide a phylogenetic analysis including seven other new metopid 18S rDNA sequences: Brachonella spiralis, B. galeata, Metopus laminarius, M. setosus, M. striatus, M. violaceus, Palmarella lata. Metopus fuscus and M. setosus form a fully supported clade, challenging previous morphospecies groupings. We discuss some ambiguities of armophorid morphologic terminology in the earlier literature. Our phylogenetic analysis of Idaho metopids indicates that the genera Metopus and Brachonella are both nonmonophyletic.
\end{abstract}

Keywords: Anaerobic ciliates; Armophorida; Brachonella; cortical granules; morphospecies; silver impregnation. 


\section{Introduction}

Metopus Claparède \& Lachmann, 1858 is a species-rich genus comprising a widely distributed group of hydrogenosome-bearing ciliates inhabiting anaerobic or microaerophilic freshwater, terrestrial and marine habitats (Corliss 1979; Lynn 2008). They are characterized morphologically by a leftward torsion of the anterior cell portion with a frontal lobe overhanging an obliquely situated adoral zone of membranelles (Esteban et al. 1995; Foissner et al. 1992; Jankowski 1964a, b; Kahl 1927). Kahl (1927) separated the genus into six informal groups according to body shape and characteristics of the peristomial structures. Several attempts at revision (Esteban et al. 1995; Jankowski 1964b; Kahl 1927; Wetzel 1928) have resulted in more contention than clarity (Dragesco 1996; Foissner and Agatha 1999; Kahl 1929). Unfortunately, the detailed morphologic and morphometric data required for such efforts are still lacking for armophorids in general and Metopus in particular (Dragesco 1996; Foissner and Agatha 1999). An estimate (Roskov et al. 2013) at this writing includes 78 nominal species, 23 infraspecific taxa and 26 supposed synonyms. Although protist species definitions, in general, remain problematic, the establishment of a coherent taxonomy of Metopus, will require much more detailed morphologic, molecular and ecological data (Boenigk et al. 2012).

One of the largest Metopus, M. fuscus Kahl, 1927, belongs to Kahl's third group that also includes the type species Metopus es (Müller, 1776) Lauterborn, 1916. We found a population of Metopus fuscus, during a broader study of free-living armophorids from Idaho, USA. In this report, we provide a detailed morphologic description, morphometrics, and 18S rDNA sequence of a North American population of $M$. fuscus and compare it with previous descriptions. A phylogenetic analysis includes the Idaho M. fuscus and seven other newly sequenced metopids. We also discuss the implications of our findings in relation to the shortcomings of the 
"morphospecies" concept as it has been applied to the free-living Armophorida (Esteban et al.

1995; Finlay et al. 1996).

\section{Material and Methods}

\section{Collection data}

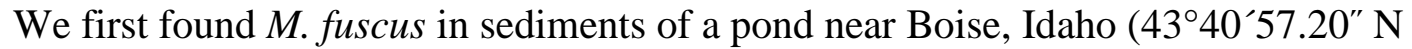

$116^{\circ} 15^{\prime} 15.44^{\prime \prime} \mathrm{W}$; elev. $873 \mathrm{~m}$ ) in June 2006. The locality is described in detail in the occurrence and ecology section below. The current report is based on this population collected from the original site and a subsample maintained for the past seven years in an open garden tub in Boise. The pond population and the garden tub population are indistinguishable. Thus, the results for both populations are combined. Attempts to establish pure cultures were unsuccessful.

Conductivity measurements were done directly on water samples using an ExStik EC meter (Spectrum Technologies, Inc. Plainfield, IL, USA).

In addition to the perennial population of M. fuscus, this open mesocosm supports a diverse community of other armophorids including Metopus striatus, M. laminarius, M. setosus, M. violaceus, Brachonella galeata, B. spiralis, and Palmarella lata for morphologic and molecular studies. These taxa will be described in a separate report. Identifications were based on previous descriptions (Foissner et al. 1992; Jankowski 1964b; Kahl 1926, 1927, 1929, 1931, 1932).

\section{Morphologic methods}


Living cells were studied at magnifications of 40-1000X with brightfield, phase- and differential interference contrast illumination using a Zeiss Axioskop 2 plus microscope (Carl Zeiss Microscopy, LLC, Thornwood, NY, USA), a Flex digital camera, and calibrated Spot imaging software (Diagnostic Instruments, Inc., Sterling Heights, MI, USA). Video imaging was done using an Olympus BX53 microscope (Olympus America, Center Valley, PA, USA) and Canon 6D camera (Canon Inc., Tokyo, Japan). In vivo measurements were made from photomicrographs of freely swimming cells. Attempts to induce formation of resting cysts by starvation in filtered $(0.22 \mu \mathrm{m}$ pore size) site water were unsuccessful as cells quickly died. Protargol impregnation, methyl green-pyronin staining, and scanning electron microscopy (SEM) were done according to Vd’ačný and Foissner (2012). Cells were fixed in 10\% formalin for protargol impregnation and a 1:1 mixture of $2 \%$ osmium tetroxide and aqueous $2.5 \%$ glutaraldehyde for SEM. Statistical analyses were performed using MedCalc for Windows, version 11.2 (MedCalc Software, Mariakerke, Belgium). All drawings were based on microphotographs.

\section{DNA extraction, amplification and sequencing}

Cells from the tub population were selected using a stereomicroscope (90X) and washed three times in filtered $(0.22 \mu \mathrm{m}$ pore size $)$ Eau de Volvic mineral water. Single cells were placed in $0.2 \mathrm{ml} \mathrm{PCR}$ tubes with $50 \mu \mathrm{l}$ of EB buffer (Qiagen, Valencia, CA, USA) and stored at $-20^{\circ} \mathrm{C}$. DNA was extracted from each of four cells using a modified Chelex method (Strüder-Kypke and Lynn 2003) and the 18S rDNA was amplified and sequenced as previously described (Bourland et al. 2012). Chromatograms were manually edited using 4-Peaks (Griekspoor and Groothuis 2006) and assembled into contiguous sequences using CAP3 (Huang and Madan 1999). 


\section{Phylogenetic analyses}

To determine the phylogenetic position of M. fuscus, we analyzed an alignment comprising $18 \mathrm{~S}$ rDNA sequences of seven taxa (three belonging to Armophorida and four to Clevelandellida) from GenBank. Metopus fuscus and seven other armophorids were newly sequenced in the present study (Figs 46-52). Two spirotrich taxa (Metaurostylopsis and Phacodinium) were used as outgroup. Alignments were constructed using MAFFT (Katoh and Toh 2008) based on primary structure. Ambiguously aligned regions were edited by eye. jModelTest was employed to find the model of nucleotide substitution that best fit the data (Posada 2008). The General-Time-Reversible model with invariable sites and gamma distribution $(\mathrm{G}+\mathrm{I}+\Gamma)$ was chosen under the Akaike Information (AI) Criterion. This model was implemented in MrBayes (Ronquist and Huelsenbeck 2003) on the CIPRES Portal V 1.15 (Miller et al. 2009), with support from four simultaneous MCMC chains run for five million generations sampling every 1000 generations. The first $25 \%$ of sampled trees were considered burn-in trees and were discarded prior to tree reconstruction. A 50\% majority-rule consensus of the remaining trees was used to calculate posterior probability (PP) for Bayesian inference (BI). The maximum likelihood (ML) analysis was implemented on the CIPRES Portal, using RAxML with settings as described in Stamatakis et al. (2008). Support for ML analyses came from 1000 bootstrap replicates using heuristic searches. We considered bootstrap values $<70$ as low, 70-94 as moderate, and $\geq 95$ as high support (Hillis and Bull 1993). For posterior probabilities, we considered values $<0.70$ as low, $0.70-0.94$ as moderate, and $\geq 0.95$ as high support.

\section{Topology hypothesis testing}

Constrained trees were created and compared with the unconstrained (i.e. best scoring) ML tree topology, generating a file of per-site log-likelihoods in the RAxML framework 
(Stamatakis et al. 2008) for comparison of constrained and unconstrained tree topologies. To this end, the approximately unbiased (AU) test in CONSEL ver. 0.1k (Shimodaira 2002, 2008;

Shimodaira and Hasegawa 2001) was applied. A $p$-value of $<0.05$ was chosen for rejection of the null hypothesis.

\section{Terminology}

Terminology is according to Foissner and Agatha (1999), Jankowski (1964b), Lynn (2008) and Rosati and Modeo (2003). We define the ventral side of the cell as that surface on which the terminus of the adoral zone (and the cytostome) is at the right margin. We propose that the ventral surface for metopids and caenomorphids be defined as that surface bearing the proximal end of the adoral zone (and the cell mouth). The remaining aspects (left, dorsal and right) would be identified according to this objectively identifiable landmark. We believe adoption of this proposed definition would provide standardization between previous and forthcoming descriptions and redescriptions of metopids and caenomorphids, avoiding the sometimes ambiguous, awkward and lengthy explanations found necessary by earlier authors (Jankowski 1964b; Stein 1867; Wetzel 1928). Classification is according to Lynn (2008).

\section{Results}

Class Armophorea Lynn, 2004

Order Armophorida Jankowski, 1964

Family Metopidae Kahl, 1927

Genus Metopus Claparède \& Lachmann, 1858

Metopus fuscus Kahl, 1927 
1927 Metopus fuscus - Kahl, Arch. Protistenk. 50, 147, Fig. 14a-d (original description; no type material available).

1928 Metopus fuscus - Wetzel, Z. Morphol. Ökol. Tiere 13, 217, Abb. 14d (taxonomic revision).

1929 Metopus fuscus - Kahl, Z. Morphol. Ökol. Tiere 15, 725, Abb. 2a,b (rebuttal to Wetzel's [1928] revision).

1931 Metopus fuscus - Kahl, Mikrokosmos 24, 9, Tafel 1, Bild 12 (brief review, illustration with elongated caudal cilia).

1932 Metopus fuscus - Kahl, Tierwelt Dtl. 25, 413, Fig. 70, Bild 15, 16 (brief redescription with notes on a smaller sized [120-150 $\mu \mathrm{m}]$ population).

1947 Metopus fuscus - Kudo, Protozoology, p. 778, Fig. 348f (abbreviated description and illustration borrowed from Kahl [1927]).

1963 Metopus fuscus - Lundin and West, The Free-Living Protozoa of the Upper Peninsula of Michigan, p. 89, Plate 23, Fig. 6 (no description, one line drawing without scale).

1964 Metopus fuscus - Jankowski, Zool. Zh. 43, 505 (taxonomic revision, placement in subgenus Metopus (Metopus); without illustration).

1964 Metopus fuscus - Jankowski, Arch. Protistenk. 107, 192, Fig.3a-c (taxonomic revision, brief description of Russian population).

1968 Metopus jankowskii - Dragesco, Ann. Fac. Sci. Cameroun 1, 77, Figs. 1A,B, 2 (first subjective synonym according to Esteban et al. [1995]).

1977 Metopus fuscus - Mahajan, Rec. zool. Surv. India 72, 220, Fig. 2m (description and illustration conflicting for size). 
NOTICE: this is the author's version of a work that was accepted for publication in European Journal of Protistology. Changes resulting from the publishing process, such as peer review, editing, corrections, structural formatting, and other quality control mechanisms may not be reflected in this document. Changes may have been made to this work since it was submitted for publication. A definitive version was subsequently published in European Jouranl of Protistology, (2014). DOI: 10.1016/j.ejop.2014.01.002

1983 Metopus fuscus - Alekperov, Zool. Zh. 62, 334 (description of freshwater population from Azerbaijani sturgeon-rearing ponds, probable misidentification).

1984 Metopus fuscoides - Alekperov, Zool. Zh. 63, 1731 (second subjective synonym according to Esteban et al. [1995]).

1992 Metopus fuscus - Foissner et al., Inf. Ber. Bayer. Landesamtes Wasserwirtsch. 5/92, 400 (in vivo microphotographs without scale and illustrations from the literature, identification uncertain).

1995 Metopus fuscus - Esteban et al., Arch. Protistenk. 146, 139 (taxonomic revision).

1997 Metopus fuscus - Alekperov and Asadullayeva, Zool. Zh. 76, 1413 (description of population form Caspian Sea, Azerbaijan, probable misidentification).

Etymology. Although not stipulated by Kahl (1927), the species name fuscus derives from the Latin adjective $f u s c \cdot u s,-a,-u m$ (dark-colored) probably referring to the brown coloration. Although the gender of Metopus is neuter, the -us ending is in accordance with Article 30.1.3 (International Commission on Zoological Nomenclature 1999).

Improved diagnosis including data from the Idaho population. Body size $180-300 \times$ 50-60 $\mu \mathrm{m}$ in vivo; dorsoventrally flattened about 3:2. Body shape oblong, distinctly twisted anteriorly. Preoral dome flattened, wider than mid-body, inclined about $50^{\circ}$ to long cell axis. Posterior end rounded to acute depending on contractile vacuole status. Cortex hyaline, very thick (about $3 \mu \mathrm{m}$ ), with longitudinal folds posteriorly; cortical granules inconspicuous, colorless, approximately $0.4 \mu \mathrm{m}$ across and forming about 5 loose rows between adjacent kineties. Color golden-brown due to cytoplasmic granules. Macronucleus dumbbell-shaped to elongate ellipsoidal, extends into preoral dome, surrounded by dense envelope of bacterial endosymbionts. A single large terminal contractile vacuole. About 90 very narrowly spaced 
ciliary rows about 20 of which extend onto preoral dome. About 15-20 elongated posterior cilia.

Perizonal ciliary stripe about $20 \%$ shorter than adoral zone proximally. Adoral zone distinctly

spiraled, composed of about 85 adoral membranelles extending $60 \%$ of body length.

Description of Idaho population (Figs 1-45; Table 1). Size quite variable in vivo (140-

$260 \times 60-115 \mu \mathrm{m})$ and in protargol-impregnated specimens $(138-195 \times 57-99 \mu \mathrm{m})$. Cells

yellowish brown under low magnification. Shape oblong, distinctly twisted anteriorly, highly

variable both in vivo and after fixation, ranges from distinctly sigmoidal to elongate triangular to

less twisted and dorsoventrally convex-concave (Figs 7a-d, 10-12, 21-23, 40-44). Length:width

ratio including preoral dome $2.3: 1$ on average $(n=16)$. Preoral dome broad, flat to centrally

convex with shallow concave brim (Fig. 4); distinctly twisted to left, overhangs both right and

left margins; distal dome brim joins body at junction of right and dorsal sides; occupies about

$30 \%$ of body length when viewed ventrally. Prominent lip between perizonal stripe row 1 and

undersurface of dome canopy (Figs 40, 45). Body posterior to preoral dome with distinct

longitudinal cortical fluting during contractile vacuole systole, thus posterior end quite variable

from acute to broadly rounded (Figs 10-13). Macronucleus occupies about $40 \%$ of body length

in vivo and 35\% in protargol preparations; usually broad dumbbell-shaped (90\% of 11 specimens

in vivo, $75 \%$ of 111 protargol impregnated specimens), sometimes broadly ellipsoidal (15\%,

$17 / 111)$, clavate $(6 \%, 7 / 111)$ or ovoidal $(4 \%, 4 / 111)$; extends into preoral dome; nucleoli

inconspicuous; invariably surrounded by dense envelope of $2 \mu \mathrm{m}$-long, blunt rod-shaped

endosymbiotic bacteria (Figs 1, 6, 26, 33, 38). Micronucleus ellipsoidal, near macronuclear

isthmus (Fig. 38). Cytopyge slit-like, subterminal (Fig. 34). Contractile vacuole large, terminal,

obconical, excretory pore not observed (Figs 1, 10, 14, 19). Cortex flexible and thick, i.e.,

forming a distinct approximately $3-\mu \mathrm{m}$ hyaline layer in vivo; finely furrowed by somatic 
NOTICE: this is the author's version of a work that was accepted for publication in European Journal of Protistology. Changes resulting from the publishing process, such as peer review, editing, corrections, structural formatting, and other quality control mechanisms may not be reflected in this document. Changes may have been made to this work since it was submitted for publication. A definitive version was subsequently published in European Jouranl of Protistology, (2014). DOI: 10.1016/j.ejop.2014.01.002

kineties; coarser structures recognizable in optical sections through cortex (Fig. 14). Cortical granules spherical, i.e, about $0.4 \mu \mathrm{m}$ across in vivo, but becoming rod-shaped after protargol impregnation; arranged in five loose rows between each two kineties; colorless in vivo, impregnate faintly with protargol but intensely with silver carbonate, stain light pink with methyl green-pyronin (Figs 16, 30, 35). Food vacuoles up to $35 \mu \mathrm{m}$ in diameter (Figs 1, 15). Movement leisurely, corkscrew-like; rotates on long axis.

Ordinary somatic cilia about $12 \mu \mathrm{m}$ long in vivo, perizonal stripe cilia about $18 \mu \mathrm{m}$ in vivo; about 15-20 elongated, i.e., about $50 \mu \mathrm{m}$-long, cilia sparsely distributed over posterior third of body (Fig. 14), lank during swimming, stiff at rest, fragile and thus often missing in fixed specimens (Figs 1, 10, 18, 20). On average 71 narrowly spaced (interkinetal distance about $2 \mu \mathrm{m}$ in vivo) somatic kineties; an average of 21 more widely spaced dome kineties converging near distal end of perizonal stripe; dorsal kineties sometimes shortened posteriorly. Stripe composed of dikinetids arranged in five equally long rows, extending near margin of preoral dome to reach the level of four fifths of adoral zone of membranelles; stripe rows 1 and 2 very close together, while rows 3-5 more widely separated from each other, and row 5 separated from dome kinety 1 by a conspicuous gap. Ordinary somatic kineties comprised of densely spaced (intrakinetal distance about $1.5 \mu \mathrm{m}$ in vivo) dikinetids often with only posterior basal body ciliated. Dikinetids of perizonal stripe and most dome kineties have both basal bodies ciliated; axis of very densely spaced dikinetids of perizonal stripe rows 1 and 2 parallel to kinety axis; more loosely spaced dikinetids of rows 3 and 4 inclined about $45^{\circ}$ to kinety axis, dikinetids of row 5 only slightly inclined without "false kinety" pattern (Figs 2-5, 9, 21-25, 28).

Two fibrillar structures associated with posterior basal body of dikinetids in protargol preparations, obscured together with ciliature in silver carbonate preparations by intensely 
impregnated cortical granules. First fibrillar structure, possibly the kinetodesma, projects to right perpendicularly to kinety axis, about $0.3 \mu \mathrm{m}$ long in perizonal rows 1 and 2 , about $0.6 \mu \mathrm{m}$ long in perizonal rows 3 and 4 as well as in dome kineties, up to $6 \mu \mathrm{m}$ long in perizonal row 5 and dome kineties 2 and 3 (Fig. 35). Second fibrillar structure visible as interkinetal striations in vivo, comprises about 3 longitudinal interkinetal fibrils, probably postciliary microtubular ribbons (Figs 17, 36).

Adoral zone of membranelles comprised of about 85 membranelles separated by prominent intermembranellar ridges in SEM; occupies about $60 \%$ of body length; spirals about $180^{\circ}$ across dorsal side, nearly transversely across left side, descending nearly vertically to end on right of ventral side; proximal portion enclosed in buccal cavity. Proximal three or four membranelles short, rectangular composed of about five rows of four basal bodies; mid adoral zone membranelles longest (about $16 \mu \mathrm{m}$ ), composed of four files of basal bodies; distal membranelles comprised of four files, three long and one short (three basal bodies) anterior file at right end (Figs 1-5, 7a-d, 8, 10-14, 20-27, 32, 36, 38). Undersurface of preoral dome an arched finely ribbed canopy, completely overhanging adoral zone. Paroral membrane originates in buccal cavity at proximal end of adoral zone, extends to undersurface of preoral dome comprised of single file of ciliated basal bodies (Figs 1, 33, 37, 40, 44, 45). Extensive irregular network of fibers extends from adoral zone, inserting on posterior cortex in protargol preparations (Figs 20,31). Cytopharyngeal fibers curve transversely or anteriorly from cytostome as a long, slender funnel (Figs 1, 31, 33). Resting cysts not observed.

\section{Conjugation, regeneration and morphogenesis}


Conjugants were rarely observed. Conjugation is anisogmaic (10-20\% size difference between conjugants) and homopolar (Fig. 15). We encountered a single instance of partial cortical regeneration (Fig. 27). Division, only fleetingly observed with the dissecting microscope, occurs in the free-swimming state. Due to the paucity of material, we could not document the details of morphogenesis. Foissner and Agatha (1999) also noted the rarity of $M$. hasei dividers in raw cultures.

\section{Molecular phylogeny}

The 18S rRNA gene of the Idaho M. fuscus comprises 1668 bp (excluding primer sequences) and a G/C content of $43 \%$. The $18 \mathrm{~S}$ rDNA sequences from four individuals were identical (GenBank Acc. No. KF607083). Phylogenetic analyses by BI and ML yielded trees of identical topology but with higher nodal support in BI than the more conservative ML analysis (Fig. 64). Metopus fuscus and M. setosus form a clade with full support in both analyses.

Palmarella lata sensu Jankowski (1964b) is sister to this clade with strong support from BI (0.95), but low support in ML (bootstrap 56\%). However, the monophyly of the clade (M. fuscus + M. setosus + Palmarella lata $)$ is not rejected by the AU test $(p=0.48)$. The AU test rejects monophyly of the sequenced Metopus $(p=0.001)$ and Brachonella species $(p<0.001)$. Our analyses show strong (BI) to moderate (ML) support for the sister group relationship of armophorids and the clevelandellids (Lynn 2008; van Hoeck et al. 1998).

\section{Voucher material}

Five voucher slides with many protargol-impregnated specimens are deposited in the Biology Center of the Museum of Natural History of Upper Austria, Linz (LI). Pertinent cells are marked on the coverslip by black ink circles. 

publishing process, such as peer review, editing, corrections, structural formatting, and other quality control mechanisms may not be reflected in this document. Changes may have been made to this work since it was submitted for publication. A definitive version was subsequently published in European Jouranl of Protistology, (2014). DOI: 10.1016/j.ejop.2014.01.002

\section{Discussion}

\section{Comparison with original description}

Kahl (1927) discovered M. fuscus in a similar habitat to the Idaho population, i.e., sapropelic sediments in a marshy pond. He described it as a large species distinguished by brown coloration from "coarse" cortical and cytoplasmic granules, the latter especially dense around the large, elongated ellipsoidal macronucleus. He noted the thick hyaline cortex and the very narrowly spaced $(2 \mu \mathrm{m})$ ciliary rows and longer posterior "bristles" (in sketches( not shown). Kahl included long caudal cilia in later (1929) illustrations (Fig. 55) and described "...sparse, very fine caudal cilia, which, however, seem to be often completely absent" (Kahl 1932). The spiraled adoral zone extended proximally to the middle on the right. The two populations show slight differences in macronuclear size (35\% vs. $22 \%$ of body length on average), shape (usually dumbbell-like vs. ellipsoidal), and location (extending into preoral dome vs. no such extension). Kahl $(1927,1932)$ did not state the number of ciliary rows for M. fuscus, but a calculation based on the given body width and interkinetal distance of $2 \mu \mathrm{m}$ yields a number of about $80-95$ somatic kineties. This is only an approximation since there is some question of systematic undermeasurement in Kahl's publications prior to 1930 (Foissner and Wenzel 2004). The accumulation of brown cytoplasmic "granules" around the macronucleus (Kahl 1927) almost certainly corresponds to the perinuclear endosymbionts in our population. He later noted the absence of an anterior cytoplasmic granule cluster (Körnerhaufen) and mentioned finding a smaller (120-150 $\mu \mathrm{m})$ population (Kahl 1931, 1932). The Idaho population of M. fuscus matches these features closely except for the cortical granulation. This is discussed in detail below. The "canals" of the contractile vacuole described by Kahl (1927) and Jankowski (1964b) actually represent the attenuated periphery of the obconical contractile vacuole when (as is often the case) 
NOTICE: this is the author's version of a work that was accepted for publication in European Journal of Protistology. Changes resulting from the publishing process, such as peer review, editing, corrections, structural formatting, and other quality control mechanisms may not be reflected in this document. Changes may have been made to this work since it was submitted for publication. A definitive version was subsequently published in European Jouranl of Protistology, (2014). DOI: 10.1016/j.ejop.2014.01.002

it is deeply indented by a single large food vacuole (Fig. 15). This phenomenon is mentioned, but not illustrated by Jankowski (1964b). The contractile vacuole corresponds to Type I (Patterson 1980), filling by the coalescence of contributory vesicles (Fig. 13). Kahl (1927) described conjugation details of which are also matched closely by the Idaho population (Fig. 19). Evidence of cortical regeneration was found in the Idaho population (Fig. 27). While this phenomenon is well known in hymenostomes, heterotrichs, and stichotrichine ciliates, it has not been reported in metopids (Aufderheide and Frankel 1980). A more detailed comparison of the ciliature and oral structures between the original description and the Idaho population is not possible since Kahl did not use silver impregnation for the study of his population. Despite the similarities between the Idaho population and the original description, the potentially important differences in cortical granulation argue against neotypification.

\section{Cortical granulation in metopids}

In the following discussion, we consider protrichocysts, mucocysts and cortical granules as synonymous (Rosati and Modeo 2003). Admittedly, relatively little is known about their prevalence, structure and function in metopid ciliates.

Kahl is uncharacteristically inconsistent in his description of "protrichocysts" in $M$. fuscus. In the original description, Kahl (1927) describes them as comprising a single row of very substantial alveolar granules ("sehr kräftigen alveolaren Körner") in the narrow interkinetal spaces. Although Kahl $(1927,1932)$ usually mentioned protrichocysts when describing $M$. fuscus, in some instances (Kahl 1929, 1931) he neglects them completely. In the key for $M$. fuscus (Kahl 1932) they are described as fine-grained or very fine rod-shaped ("feinkörnig oder sehr fein stäbchenförmig" in comparison to M. acidiferus) yet, in the following description for M. fuscus, as coarse (“derber”). His illustrations of M. fuscus (Kahl 1927, 1929, 1931, 1932) are 
NOTICE: this is the author's version of a work that was accepted for publication in European Journal of Protistology. Changes resulting from the publishing process, such as peer review, editing, corrections, structural formatting, and other quality control mechanisms may not be reflected in this document. Changes may have been made to this work since it was submitted for publication. A definitive version was subsequently published in European Jouranl of Protistology, (2014). DOI: 10.1016/j.ejop.2014.01.002

also ambiguous, omitting protrichocysts (Kahl 1929), showing them as fine rods (Kahl 1931) or as fine interkinetal granules (Kahl 1932). Schulze (1959) considered metopid "protrichocysts" in detail. Those of M. es are numerous, spherical and about $0.2 \mu \mathrm{m}$ in diameter, similar to those of the North American population of M. fuscus (Foissner et al. 1992, p. 406, Fig. 4e). According to Jankowski (1964b), the Russian population of M. fuscus was "devoid of trichocysts" and he mentioned no other cortical granulation (i.e. mucocysts). Foissner and Agatha (1999) describe loose rows of colorless $0.2-0.5 \mu \mathrm{m}$ granules in $M$. hasei and M. inversus. Metopus striatus McMurrich 1884 has conspicuous 2.5 x $0.8 \mu \mathrm{m}$ rod-shaped extrusomes (Fig. 50). Inconspicuous small colorless interkinetal granules likely represent a plesiomorphic character in metopids, however much more data is needed before the true taxonomic importance of this character can be established for this group. Foissner et al. (1992, p. 416 Figs 82, 83) label a metopid having a cortical layer of relatively large globular structures as M. fuscus. These "granules" might be similar to those described by Kahl (1927), but because no size is given and cell shape is inconsistent with M. fuscus (e.g. size and shape of the preoral dome, length of adoral zone and position of the cytostome) the identification is uncertain. Similar structures were seen in our population in some DIC optical sections (Figs 14, 20) but not in brightfield examinations (Figs 10, 11). They are not apparent in surface views of the cortex. Whether these might correspond to the “... sehr kräftigen alveolaren Körner...” of M. fuscus sensu Kahl (1927) will only be resolved by ultrastructural studies. Due to a paucity of detailed descriptions, the taxonomic importance of cortical granulation in armophorids is undetermined. A detailed discussion of the subspecies concept is beyond the scope of this paper (Patten and Unitt 2002). However, in our opinion, designation of the North American population as a subspecies on the basis of 
differences in cortical granulation would be premature. Accordingly we consider the Idaho ciliate as a North American population of M. fuscus Kahl, 1927.

\section{Synonymy (Figs 53-63)}

In considering what are now referred to as the armophorids (Lynn 2008), early taxonomists occupied either end of the admittedly subjective and continuous spectrum of "lumpers" and "splitters" (Corliss 1976). These designations are only descriptors and not pejoratives. The tension between these two philosophical tendencies is on clear display in the taxonomic history of Metopus, resulting in confusion that persists today. Those more prone to "lump" included Eberhard (1862), Kent (1880), Mermod (1914), Roux (1901), Stein (1867), and Wetzel (1928). Of these, perhaps the most enthusiastic was Eberhard (1862), describing what would now be considered three genera (Brachonella, Caenomorpha and Metopus) as a single species (Strombidium polymorphum). The others considered the wide diversity of morphologic forms observed in the sapropel, not as many separate species but as a multitude of "transitional" forms of one or two species appearing in succession. Mermod (1914) proposed a polymorphic life cycle that began with a Metopus sigmoides "form" and progressed through increasing body torsion and shortening and a "molting" (moue) of cilia to the final form, Caenomorpha medusula. Because conjugation was unknown for Caenomorpha at that time, it was assumed that only the "Metopus stage" could reproduce.

Among the "splitters" we might include Levander (1894), Kahl (1926, 1927, 1929, 1931, 1932) and Villeneuve-Brachon (1940), and certainly, Jankowski (1964a, 1964b, 2007). Kahl's (1927) second revision of the genus included 37 species and 15 subspecies. 
To Kahl's dismay, Wetzel (1928) disparagingly reduced the number of "reliable" species to eight and rejected the infraspecific taxa altogether. One of the "reliable" species ("because of observed conjugation") was M. fuscus. In a subsequent rebuttal, Kahl (1929) contended that Wetzel's subjective bias would result in a “...very large number of erroneous synonymies...” Kahl's annoyance was understandable, not only because of Wetzel's condescending tone, but also because (among other things) he indicated that Kahl had "described as tentative synonyms [authors' translation]" M. fuscus, M. ovalis, M. barbatus and M. propagatus when, in fact, he had not. Curiously, Wetzel (1928) stops short of formally designating the "unreliable" Metopus taxa as synonyms. Kahl was vindicated, to some extent, since subsequent authors largely ignored Wetzel's opinions regarding Metopus (Dragesco 1968, 1996; Esteban et al. 1995; Foissner and Agatha 1999; Jankowski 1964a, 1964b, 2007).

Jankowski (1964a) transferred ten species to the new genera Brachonella, Cirranter (new name for the preoccupied Trochella Penard, 1922), Palmarella Jankowski, 1975 (replacement name for the preoccupied Palmarium Gajewskaja, 1925) and the resurrected genus Bothrostoma Stokes, 1887. He further subdivided Metopus into two subgenera, Metopus s. str. and Urostomides including species "grouping around the type, M. es" and rhomboid/ovoid species with equal-size anterior and posterior parts respectively (Jankowski 1964b). Esteban et al. (1995), although not citing Wetzel (1928), shared his view that the genus Metopus was rife with synonymous species. Using a "morphospecies" approach, they reduced $>75$ nominal species to only 22 species in five informal "morphotype" groups by transfer of some taxa to other genera (e.g. Copemetopus Villeneuve-Brachon, 1940) and by synonymizing many others. In the most egregious example they synonymized M. striatus McMurrich, 1884 with 13 other nominal species. 
Esteban et al. (1995) proposed M. jankowskii Dragesco, 1968 as a junior synonym of $M$. fuscus Kahl, 1927. Both are similar in size and shape, the fibrillar system between the adoral zone and the posterior cortex, and elongated posterior cilia (Dragesco apparently overlooked Kahl's mention of these in M. fuscus). In our opinion, synonymization was premature, for several reasons: (1) M. fuscus has been reported only from freshwater habitats while M. jankowskii has been found only in marine or brackish water habitats, (2) Metopus jankowskii has a distinctive macronuclear morphology (sharply tapered anteriorly vs. bluntly rounded at both ends), (3) Metopus jankowskii has an aggregation of cytoplasmic granules just posterior to the adoral zone which is never seen in M. fuscus, (4) the curious "button"-like structure at the terminus of the cytopharyngeal funnel in M. jankowskii is absent in M. fuscus, (5) perinuclear endosymbionts are absent in M. jankowskii but prominent in M. fuscus. Until further characterization of $M$. jankowskii is available, including molecular data, we reject the synonymy of M. jankowskii and M. fuscus.

Esteban et al. (1995) also synonymized the freshwater species M. fuscoides Alekperov, 1984 with M. fuscus. The two species differ in the following features: (1) cell size (300-320 vs. 138-195 $\mu \mathrm{m}$ after fixation), (2) number of adoral membranelles (40-45 vs. $74-103$ after silver impregnation), (3) number of dome kineties (7-8 vs. 18-24 after silver impregnation), (4) location of macronucleus (cell center vs. anterior half), and (5) contractile vacuole (small vs. large). Alekperov (1984) obviously follows Jankowski’s (1964b) estimate of somatic kinety number for M. fuscus when comparing the two species. Because of these numerous differences, we propose that synonymy between $M$. fuscoides and $M$. fuscus should be rejected.

The Idaho population differs from Jankowski's Russian specimens in only two characteristics: (1) elongated caudal cilia (likely overlooked), and (2) the number of ciliary rows 
(80-108 vs. 45-50). The meristic discrepancy is difficult to explain since all other features match

closely (e.g. size, shape, macronuclear details, perinuclear "granules", dense ciliation, absence of

trichocysts, and contractile vacuole shape). The possibility of a misobservation cannot be

excluded. Wide variability in posterior body shape largely corresponds to the contractile vacuole

cycle (i.e. broadly rounded in diastole and acute after systole). Jankowski’s perinuclear

"granules" doubtless correspond to the perinuclear endosymbionts (Figs 1, 25, 31).

Likely misidentifications as M. fuscus include those of Alekperov (1983, Fig. 57),

Alekperov and Asadullayeva (1997, Fig. 61), and Mahajan (1977, Fig. 60). Based on illustrations and descriptions, all are substantially smaller and have many fewer ciliary rows and adoral membranelles than previous descriptions (Jankowski 1964b; Kahl 1927, 1929, 1931, 1932). A report from Michigan, USA (Lundin and West 1963, Fig. 59) with only a simple line drawing and no scale or description is indeterminate. The identification by Foissner et al. (1992, Fig. 13) is uncertain as described above in the section on cortical granulation.

\section{Comparison with related taxa}

Metopus es (Müller, 1776), M. laminarius Kahl, 1927 and starved M. paeleformis Kahl, 1927 in culture can reach lengths of > $200 \mu \mathrm{m}$ (Esteban et al. 1995; Kahl 1932), but these species have distinctly different cell shapes, i.e. slender, less spiraled, with less developed preoral dome, shorter adoral zone and different macronuclear shape, i.e. ovoid in M. es and M. laminarius and globular to slender elongate in M. paeleformis (Esteban et al. 1995; Foissner et al. 2002).

Metopus fuscus differs from the large (200-300 $\mu \mathrm{m})$ morph of $M$. extentus briefly described by Villeneuve-Brachon (1940) in the number and spacing of kineties (about 70, narrowly spaced vs. 20-24, loosely spaced), shape of the macronucleus (dumbbell shaped vs. spherical), cortical 
granules (tiny, spherical vs. conical), and habitat (freshwater vs. brackish water). The form

Metopus contortus major Kahl, 1932 was elevated to species rank by Esteban et al. (1995).

Metopus fuscus differs from Metopus major: (1) in body shape (length:width ratio about 2.3 vs.

about 4), (2) the preoral dome (broad and flat vs. approximate width of body), (3) kinety number

(about 90 vs. 50-55), (4) habitat (freshwater vs. brackish water), (5) location of the micronucleus (adjacent to midportion of macronucleus in mid cell vs. distant from macronucleus in posterior cell). The latter feature is quite unusual but the description of the micronucleus in M. major by Esteban et al. (1995) must be accepted at the present state of knowledge. Kahl (1932) did not mention the nuclear apparatus in his original description of M. contortus f. major. Kahl (1927) suggested a close relationship between $M$. fuscus and $M$. propagatus because the dense ciliation and thick ectoplasm of both species. Metopus fuscus lacks the characteristic slender, curved "tail" of M. propagatus.

\section{Occurrence and ecology}

Metopus fuscus inhabits sulfidic bottom sediments. Kahl (1927) discovered M. fuscus in the sapropel of a pond in Hamburg's Botanical Garden in Germany. Jankowski (1964b) found it in ponds around St. Petersburg, Russia. Reports of M. fuscus from Germany (Kreutz and Foissner 2006), Italy (Madoni and Sartore 2003), Mexico (Nomdedeu 1988), Slovakia (Matis et al. 1996), Ukraine (Koval'chuck 1980), U.S.A. (Noland 1927), and Thailand (Charubhun and Charubhun 2000) are all unsubstantiated by illustrations; however, it is likely that $M$. fuscus is a widely distributed (at least in Laurasian habitats), but poorly known species. Other illustrated records have been discussed above in the synonymy section. To date, all reports are from freshwater habitats. Our population of $M$. fuscus was originally collected from a permanent, 
NOTICE: this is the author's version of a work that was accepted for publication in European Journal of Protistology. Changes resulting from the publishing process, such as peer review, editing, corrections, structural formatting, and other quality control mechanisms may not be reflected in this document. Changes may have been made to this work since it was submitted for publication. A definitive version was subsequently published in European Jouranl of Protistology, (2014). DOI: 10.1016/j.ejop.2014.01.002

natural eutrophic Lemna pond with bordering Typha lattifolia near Boise, Idaho, USA. To date, we have found M. fuscus only at this location. A population from this site has been maintained in a 901 garden tub since 2006. Tap water drip lines maintain the water level. The water is circumneutral (pH 6.53) and nonsaline (conductivity $117 \mu \mathrm{S})$. The tub is exposed year-round to ambient conditions including precipitation, high summer temperatures (up to $43^{\circ} \mathrm{C}$ ) and winter freezing. We have found M. fuscus in the above-described pond several times since 2006. Madoni and Sartore (2003) reported very low abundances of $M$. fuscus, except in spring and summer months, but we have found abundant populations year-round both at the pond site and in the garden tub. Kahl $(1927,1932)$ also found M. fuscus most commonly during winter.

Food vacuoles usually contain Lamprocystis roseopersicina, a common phototrophic purple sulfur bacterium with characteristic motile spherical colonies of diploccocal cells that contain elemental sulfur granules. Food also includes dinoflagellates (Peridinium sp.), pennate diatoms (seen in 28 of 218 [about 13\%] fixed specimens), green algae, and colorless flagellates (Figs 1, 19, 21, 29). Although usually considered as bacterivores (Lynn 2008), our findings and those of Schulze (1959) indicate that larger Metopus species are likely ominivorous. Metopus fuscus is an aerotolerant anaerobe that survives without difficulty for up to seven days in shallow jars open to the air. Metopus fuscus has not been reliably documented from soils, brackish water or saltwater habitats.

\section{Molecular phylogeny of armophorids}

Orders Armophorida Jankowski, 1964 and Clevlandellida de Puytorac and Grain, 1976 comprise the class Armophorea Lynn, 2004. Although previously included in the Armophorea, molecular studies indicate the Odontostomatida now belong to Plagiopylea (Stoeck et al. 2007). 
Armophorea and Plagiopylea are designated as "riboclasses" because their constituent orders lack obvious morphologic synapomorphies but are closely related by $18 \mathrm{~S}$ rDNA sequences (Lynn 2004, 2008). At the time of this writing there were only two metopid and one caenomorphid 18S rDNA sequences from morphologically well-characterized taxa in GenBank.

In the current report we add sequences from seven additional Idaho metopids (Figs 46-52).

There is still no gene sequence for the type species M. es.

The nonmonophyly of genera Metopus and Brachonella is indicated by the phylogenetic tree and supported by further statistical analysis (Table 2). This should not be surprising in view of the incomplete morphologic data; that is to say, the "morphospecies concept" has been applied despite an inadequate morphologic basis (Esteban et al. 1995; Finlay et al. 1996). One example of this is the unsupportable synonymy proposed between M. striatus and M. violaceus (Esteban et al. 1995). This synonymy must be rejected on both morphologic and molecular grounds (Figs $49,50,64)$. The latter species will be described in detail in a future report. Preliminary SEM and silver impregnation of the two nominal Brachonella species suggests that their distant molecular relationship (Figs 46, 47, 64) correlates with differences in their oral and somatic ciliature (unpubl. data).

In the $18 \mathrm{~S}$ rDNA phylogeny (Fig. 64), the Idaho M. fuscus is, surprisingly, most closely related to M. setosus Kahl, 1927. At the present state of knowledge these two species differ widely in size (about 210 vs. about $75 \mu \mathrm{m}$ ), shape (distinctly vs. only slightly spiraled; prominent vs. small preoral dome), and ciliature (very narrowly spaced vs. normally spaced kineties). They share only four obvious, but hardly unique, morphologic characteristics (i.e. elongated posterior cilia that stiffen at rest, numerous small cortical granules, absence of an anterior cytoplasmic granule cluster, and absence of a "false kinety" pattern in the perizonal stripe). 
The sister group relationship between the armophorids and the nyctotherids

(Clevlandellida) is moderately to strongly supported, consistent with prior studies (Miao 2009;

Stoeck et al. 2007). It is likely that more detailed study of the armophorids will shed light on morphologic synapomorphies with the Clevelandellida in the future (Lynn 2008).

\section{Future directions}

A meaningful revision of the metopids remains a distant but important goal that will require detailed descriptions of as many of the nominal species as possible (Dragesco 1996; Foissner and Agatha 1999). Because modern descriptions for most Metopus and other armophorid genera (e.g. Brachonella and Palmarella) were unavailable to Esteban et al. (1995), it is not surprising that their revision has been disputed (Dragesco 1996; Foissner et al. 1999, 2002). In his most recent revision, Jankowski (2007) complicates matters further by proposing nine "subgenera" for Metopus but labeling them as genera. Thus, the classification of the armophorids in general, and the metopids in particular, remains in disarray. Lynn (2008), although aware of it, chose not to adopt Jankowski’s classification.

The molecular characterization of armophrids is only just beginning and the current study shows that "morphotype" groupings alone have been inadequate for resolving the relationships among armophorids. Ideally, the principle of "integrative taxonomy" will be brought to bear on this problem. This method combines concise morphologic description and molecular barcoding, correlating both with ecologic characterization for species identification (Riedel et al. 2013). We believe that the morphospecies concept remains valuable and can be an important component of this approach when based on detailed morphologic and morphogenetic data. The mitochondrial cox1 gene, the most widely used molecular barcode in ciliates, is obviously inapplicable in the 
amitochondriate armophorids but alternatives (e.g. 18S rDNA and ITS) may suffice for this purpose (Schoch et al. 2012).

\section{Acknowledgements}

The authors thank two anonymous reviewers for valuable recommendations that helped improve the quality of the manuscript. We are also grateful to Drs. Denis Lynn and Peter Vd'ačný for their thoughtful suggestions. This work was partially supported by startup funds from the Boise State University Department of Biological Sciences and the DoE (National Nuclear Security Administration) under award number DE-NE0000338. 


\section{References}

Alekperov, I. K., 1983. Ciliates of pelogen in rearing ponds of the Kura experimental sturgeon hatchery. Zool. Zh. 62, 331-338.

Alekperov, I. K., 1984. New species of freshwater ciliates (Heterotrichida) from artificial water bodies of Azerbaijan. Zool. Zh. 63, 1731-1734.

Alekperov, I. K., Asadullayeva, E., 1997. New and little-known ciliates (orders NassulidaOligotrichida) from the Caspian Sea Apsheronian coast. Communication 2. Zool. Zh. 76, $1411-1417$.

Aufderheide, K. J., Frankel, J., 1980. Formation and positioning of surface-related structures in protozoa. Microbiol. Rev. 44, 252-302.

Boenigk, J., Ereshefsky, M., Hoef-Emden, K., Mallet, J., Bass, D., 2012. Concepts in protistology: species definitions and boundaries. Eur. J. Protistol. 48, 96-102.

Bourland, W. A., Hampikian, G., Vd’ačný, P., 2012. Morphology and phylogeny of a new woodruffiid ciliate, Etoschophrya inornata sp. n. (Ciliophora, Colpodea, Platyophryida), with an account on evolution of platyophryids. Zool. Scr. 41, 400-416.

Charubhun, B., Charubhun, N., 2000. Biodiversity of freshwater protozoa in Thailand. Kasetsart J. (Nat. Sci.) 34, 486-494.

Corliss, J. O., 1976. On lumpers and splitters of higher taxa in ciliate systematics. Trans. Am. Microsc. Soc. 95, 430-442.

Corliss, J. O., 1979. The Ciliated Protozoa: Characterization, Classification and Guide to the Literature. Pergamon Press, Oxford.

Dragesco, J., 1968. Metopus jankowskii n. sp., Sonderia sinuata Kahl et Discocephalus minimus n. sp., ciliés nouveaux ou mal connus. Ann. Fac. Sci. Univ. Fed. Cameroun 1, 77-88. 
Dragesco, J., 1996. Infraciliature et morphométrie de cinq espèces de ciliés mésopsammiques méditerranéens. Cah. Biol. Mar. 37, 261-293.

Eberhard, E., 1862. Zweite Abhandlung über die Infusorienwelt. Oster-progr. der Realschule zu Cobg. 1862, 1-26, Fig. 1-37.

Esteban, G. F., Fenchel, T., Finlay, B. J., 1995. Diversity of free-living morphospecies in the ciliate genus Metopus. Arch. Protistenkd. 146, 137-164.

Finlay, B. J., Corliss, J. O., Esteban, G. F., Fenchel, T., 1996. Biodiversity at the microbial level: the number of free-living ciliates in the biosphere. Q. Rev. Biol. 71, 221-237.

Foissner, W., Agatha, S., 1999. Morphology and morphogenesis of Metopus hasei Sondheim, 1929 and M. inversus (Jankowski, 1964) nov. comb. (Ciliophora, Metopida). J. Eukaryot. Microbiol. 46, 174-193.

Foissner, W., Wenzel, F., 2004. Life and legacy of an outstanding ciliate taxonomist, Alfred Kahl (1877-1946), including a facsimile of his forgotten monograph from 1943. Acta Protozool. 43, 1-69.

Foissner, W., Berger, H., Kohmann, F., 1992. Taxonomische und ökologische Revision der Ciliaten des Saprobiensystems. Band II: Petrichia, Heterotrichida, Odontostomatida. Inf. Ber. Bayer. Landesamtes Wasserwirtsch. 5/92, 1-502.

Foissner, W., Agatha, S., Berger, H., 2002. Soil ciliates (Protozoa, Ciliophora) from Namibia (Southwest Africa), with emphasis on two contrasting environments, the Etosha region and the Namib Desert. Denisia 5, 1-1459.

Griekspoor, A., Groothuis, T., 2006. 4Peaks. Available via http://mekentosj.com.

Hillis, D. M., Bull, J. J., 1993. An empirical test of bootstrapping as a method for assessing confidence in phylogenetic analysis. Syst. Biol. 42, 182-192. 
Huang, X., Madan, A., 1999. CAP3: A DNA sequence assembly program. Genome Res. 9, 868877.

International Commission on Zoological Nomenclature (ICZN), 1999. International Code of Zoological Nomenclature, fourth ed. The International Trust for Zoological Nomenclature, London.

Jankowski, A. W., 1964a. Morphology and evolution of Ciliophora I. The new system of sapropelobiotic Heterotrichida. Zool. Zh. 43, 503-517.

Jankowski, A. W., 1964b. Morphology and evolution of Ciliophora. III. Diagnoses and phylogenesis of 53 sapropelebionts, mainly of the order Heterotrichida. Arch. Protistenkd. 107, 185-294.

Jankowski, A., 2007. Phylum Ciliophora Doflein, 1901. In: Alimov, A. F. (Ed.), Protista. Part 2, Handbook on Zoology. Russian Academy of Sciences, Zoological Institute, St. Petersburg, pp. 371-993.

Kahl, A., 1926. Neue und wenig bekannte Formen der holotrichen und heterotrichen Ciliaten. Arch. Protistenkd. 55, 197-428.

Kahl, A., 1927. Neue und ergänzende Beobachtungen heterotricher Ciliaten. Arch. Protistenk. $57,121-203$.

Kahl, A., 1929. Persönliche Erwiderung auf Wetzel's Kritik an meiner Bearbeitung der Gattung Metopus (infusoria heterotricha). Z. Morphol. Ökol. Tiere 15, 723-734.

Kahl, A., 1931. Metopus, eine interessante Infusoriengattung (infusoria heterotricha). Mikrokosmos 24 (Years 1930/31), 7-12.

Kahl, A., 1932. Urtiere oder Protozoa I: Wimpertiere oder Ciliata (Infusoria) 3. Spirotricha. In: Dahl, F. (Ed.), Die Tierwelt Deutschlands. G. Fischer, Jena, pp. 399-650. 
Katoh, K., Toh, H., 2008. Recent developments in the MAFFT multiple sequence alignment program. Briefings Bioinf. 9, 286-298.

Kent, W.S., 1880-1882. A manual of the infusoria: including a description of all known flagellate, ciliate, and tentaculiferous protozoa British and foreign, and an account of the organization and affinities of the sponges. Vol. 1-3. David Bogue, London.

Koval'chuck, A. A., 1980. Some data on the fauna and ecology of Metopidae (Infusoria) in Kiev Reservoir. Hydrobiol. J. 16, 38-44.

Kreutz, M., Foissner, W., 2006. The sphagnum ponds of Simmelried in Germany: a biodiversity hot-spot for microscopic organisms. Protozool. Monogr. 3, 1-267.

Levander, K. M., 1894. Beiträge zur Kenntnis einiger Ciliaten. Acta Soc. pro Fauna Flora Fenn. 9, 389-400.

Lundin, F. C., West, L. S., 1963. The Free-Living Protozoa of the Upper Penninsula of Michigan. Northern Michigan College Press, Marquette.

Lynn, D. H., 2004. Morphology or molecules: how do we identify the major lineages of ciliates (Phylum Ciliophora)? Eur. J. Protistol. 39, 356-364.

Lynn, D. H., 2008. The Ciliated Protozoa: Characterization, Classification and Guide to the Literature, third ed. Springer, Dordrecht.

Madoni, P., Sartore, F., 2003. Long term changes in the structure of ciliate communities in a small isolated pond. Ital. J. Zool. 70, 313-320.

Mahajan, K. K., 1977. Fauna of Rajasthan protozoa (No.3). Rec. Zool. Surv. India 72, 213-225.

Matis, D., Tirjaková, E., Stloukal, E., 1996. Cilophora in the database of Slovak fauna. Folia Faunistica Slovaca 1, 3-38. 
Mermod, G., 1914. Recherches sur la faune infusorienne des tourbières et des eaux voisines de Sainte-Croix (Jura vaudois). Rev. Suisse Zool. 22, 31-114, Pl. 2,3.

Miao, M., Song, W., Clamp, J. C., Al-Rasheid, K. A. S., Al-Khedhairy, A. A., Al-Arifi, S., 2009. Further consideration of the phylogeny of some "traditional" heterotrichs (Protista, Ciliophora) of uncertain affinities, based on new sequences of the small subunit rRNA gene. J. Eukaryot. Microbiol. 56, 244-250.

Miller, M. A., Holder, M. T., Vos, R., Midford, P. E., Liebowitz, T., Chan, L., Hoover, P., Warnow, T., 2009. The CIPRES portals. Available via http://www.phylo.org/ sub_sections/portal.

Noland, L. E., 1927. Conjugation in the ciliate Metopus sigmoides C. and L. J. Morphol. 44, $341-361$.

Nomdedeu, O.V., 1988. Protozoarios ciliados de México. XXXII. Estudio ecológico de algunas especies para estimar el grado de contaminación del Río la Magdalena, México, D.F. An. del Inst. Ciencias del Mar y Limnol. 15, 229-236.

Patten, M. A., Unitt, P., 2002. Diagnosability versus mean differences of sage sparrow subspecies. Auk 119, 26-35.

Patterson, D. J., 1980. Contractile vacuoles and associated structures: their organization and function. Biol. Rev. 55, 1-46.

Posada, D., 2008. jModelTest: phylogenetic model averaging. Mol. Biol. Evol. 25, 1253-1256.

Riedel, A., Sagata, K., Suhardjono, Y. R., Tänzler, R., Balke, M., 2013. Integrative taxonomy on the fast track- towards more sustainability in biodiversity research. Front. Zool. 10, 1-9.

Ronquist, F., Huelsenbeck, J. P., 2003. MrBayes 3: Bayesian phylogenetic inference under mixed models. Bioinformatics 19, 1572-1574. 
NOTICE: this is the author's version of a work that was accepted for publication in European Journal of Protistology. Changes resulting from the publishing process, such as peer review, editing, corrections, structural formatting, and other quality control mechanisms may not be reflected in this document. Changes may have been made to this work since it was submitted for publication. A definitive version was subsequently published in European Jouranl of Protistology, (2014). DOI: 10.1016/j.ejop.2014.01.002

Rosati, G., Modeo, L., 2003. Extrusomes in ciliates: diversification, distribution, and phylogenetic implications. J. Eukaryot. Microbiol. 50, 383-402.

Roskov, Y., Kunze T., Paglinawan L., Abucay L., Orrell T., Nicolson D., Culham A., Bailly N., Kirk P., Bourgoin T., Baillargeon G., Decock W., De Wever A., Didžiulis V., (Eds),. Species 2000 \& ITIS Catalogue of Life, 24th September 2013. Digital resource at Www.catalogueoflife.org/col. Species 2000: Reading, UK, accessed October 16, 2013.

Roux, J., 1901. Faune Infusorienne des Eaux Stagnantes des Environs de Geneve. H. Kündig, Geneve.

Schoch, C. L., Seifert, K. A, Huhndorf, S., Robert, V., Spouge, J. L., Levesque, C. A., Chen, W., 2012. Nuclear ribosomal internal transcribed spacer (ITS) region as a universal DNA barcode marker for Fungi. PNAS 109, 6241-6246.

Schulze, E., 1959. Morphologische, cytologische und ökologisch-physiologische Untersuchungen an Faulschlammciliaten (Metopus sigmoides Clap. et Lachm. und Metopus contortus Lev). Arch. Protistenkd. 103, 371-426.

Shimodaira, H., 2002. An approximately unbiased test of phylogenetic tree selection. Syst. Biol. $51,492-508$.

Shimodaira, H., 2008. Testing regions with nonsmooth boundaries via multiscale bootstrap. J. Stat. Plan. Infer. 138, 1227-1241.

Shimodaira, H., Hasegawa, M., 2001. CONSEL: for assessing the confidence of phylogenetic tree selection. Bioinformatics 17, 1246-1247.

Stamatakis, A., Hoover, P., Rougemont, J. 2008. A rapid bootstrap algorithm for the RAxML web servers. Syst. Biol. 75, 758-771. 

publishing process, such as peer review, editing, corrections, structural formatting, and other quality control mechanisms may not be reflected in this document. Changes may have been made to this work since it was submitted for publication. A definitive version was subsequently published in European Jouranl of Protistology, (2014). DOI: 10.1016/j.ejop.2014.01.002

Stein, F., 1867. Der Organismus der Infusionsthiere nach eigenen Forschungen in systematischer Reihenfolge bearbeitet. II. Abtheilung. 1) Darstellung der neuesten Forschungsergebnisse über Bau, Fortpflanzung und Entwickelung der Infusionsthiere. 2) Naturgeschichte der heterotrichen Infusorien. W. Engelmann, Leipzig.

Stoeck, T., Foissner, W., Lynn, D.H., 2007. Small-subunit rRNA phylogenies suggest that Epalxella antiquorum (Penard, 1922) Corliss, 1960 (Ciliophora, Odontostomatida) is a member of the Plagyopylea. J. Eukaryot. Microbiol. 54, 436-442.

Strüder-Kypke, M. C., Lynn, D. H., 2003. Sequence analyses of the small subunit rRNA gene confirm the paraphyly of oligotrich ciliates sensu lato and support the monophyly of the subclasses Oligotrichia and Choreotrichia (Ciliophora, Spirotrichea). J. Zool. 260, 87-97. van Hoeck, A. H. A. M., van Alen, T., A., Sprakel, V. S. I., Hackstein, J. H. P., Vogels, G. D., 1998. Evolution of anaerobic ciliates from the gastrointestinal tract: phylogenetic analysis of the ribosomal repeat from Nyctotherus ovalis and its relatives. Mol. Biol. Evol. 15, 1195-1206.

Vd’ačný, P., Foissner, W., 2012. Monograph of the dileptids ( Protista, Ciliophora, Rhynchostomatia). Denisia 31, 1-529.

Villeneuve-Brachon, S., 1940. Recherches sur les ciliés hétérotriches cinétome, argyrome, myonémes, formes nouvelles ou peu connues. Arch. Zool. Expérimental Générale 87, 1$180+$ Plates I-V.

Wetzel, A., 1928. Der Faulschlamm und seine Ziliaten Leitformen. Z. Morphol. Ökol. Tiere 13, $179-328$. 


\section{Figure legends}

Figs 1-9. Metopus fuscus, Idaho population from life $(1,8)$ and after protargol impregnation $(2-$ 7, 9). 1. Ventral view of a representative specimen. 2, 3. Ventral and dorsal views of same specimen. 4, 5. Slightly anterior views of preoral dome. 6. Perinuclear endosymbionts. 7a-d. Body shape variants and course of adoral zone. 8. Semi-schematic posterior polar view showing metachronal waves of perizonal stripe cilia. 9. Orientation of perizonal stripe dikinetids. AZM, adoral zone of membranelles; D, dorsal; DK1, preoral dome kinety 1; L, left; PS, perizonal ciliary stripe; PS1, perizonal ciliary stripe kinety 1; R, right; V, ventral. Scale bars: $50 \mu \mathrm{m}(1-5$, $7 \mathrm{a}-\mathrm{d}), 25 \mu \mathrm{m},(8), 5 \mu \mathrm{m}(6,9)$.

Figs 10-20. Metopus fuscus, Idaho population from life, with brightfield $(10,11,15,19)$ and differential interference contrast illumination $(12,14,16-18,20)$ and from Foissner et al. 1992 (13). 10. Right view showing proximal end of the adoral zone (white arrowhead), elongated posterior cilia (black arrowheads), perizonal stripe cilia (white arrow) and contractile vacuole in diastole (white asterisk). 11. Ventral view showing posterior cortical fold (opposed white arrowheads) and proximal margin of preoral dome (black arrowhead). 12. Ventral view showing contributory vesicles of contractile vacuole (white arrowheads). 13. Metopus fuscus (from Foissner et al. 1992) with "fringe of extrusomes" (arrows). Size not given. 14. Optical section showing layer of oblong cortical granules (white arrowheads). 15. Thick hyaline cortex (opposed arrowheads). 16. Interkinetal cortical granules in a strongly squashed cell (arrowheads). 17. Interkinetal fibrils, possibly postciliary microtubular ribbons (arrowheads). 18. Optical section of individual at rest showing stiffened elongated posterior cilia (white arrowheads), ordinary 
somatic cilia (black arrowheads) and proximal end of adoral zone (white arrow). 19. Anisogamic homopolar conjugants. Large food vacuoles containing Lamprocystis roseopersicina impinge on the contractile vacuole (arrows). A smaller food vacuole contains a green alga (arrowhead). 20. Posterior region (ventral view) showing metachronal somatic ciliary waves (black arrowheads), stiffened long posterior cilia (white arrowheads), thick cortex (opposed arrows), and contractile vacuole in mid-diastole (asterisk). AZM, adoral zone of membranelles; D, preoral dome; Ma, macronucleus; pK, preoral dome (Kuppe); S1, mouth (Schlund). Scale bars: $50 \mu \mathrm{m}$ (10-12, 18, 19), $25 \mu \mathrm{m}(20), 10 \mu \mathrm{m}(14,15), 5 \mu \mathrm{m}(16,17)$.

Figs 21-30. Metopus fuscus, Idaho population after protargol impregnation (21-29) and silver carbonate impregnation (30). 21. Right ventrolateral view showing purple sulfur bacteria in food vacuoles (white arrowheads) and cytoplasmic fibrils (black arrowheads). 22. Dorsal view showing distal end of adoral zone (black arrowhead) and perizonal stripe (white arrowhead). Note shortened dorsal kineties (arrows) and the location of the proximal end of the adoral zone on the ventral side (asterisk). 23. Right dorsolateral view showing dome kineties. 24. Right ventrolateral view showing proximal end of perizonal stripe (white arrowhead). Note the cortical fold (opposing arrowheads) and narrow posterior end (arrow) that occur with collapse (systole) of contractile vacuole. 25. Right ventrolateral view showing broadly rounded posterior end (arrow) characteristic of cells when contractile vacuole is full (end diastole). 26. Dorsal view showing endosymbionts (white arrowheads) enveloping the macronucleus and the proximal adoral zone on the ventral side (asterisk). 27. Specimen undergoing partial regeneration of adoral membranelles (black arrow), perizonal stripe kineties (white arrowhead) and preoral dome kineties (black arrowhead). 28. Left lateral view showing preoral dome canopy (white 
arrowhead) overhanging the adoral zone (white arrow). The preoral dome kineties are separated from the perizonal stripe by a wide interkinetal gap (black arrowhead). 29. Ingested pennate diatom frustules (arrowheads). 30. Left lateral view showing intense impregnation of cortical granules after silver carbonate impregnation. AZ, adoral zone of membranelles; CV, contractile vacuole; DK, preoral dome kineties; DK1, preoral dome kinety 1; Ma, macronucleus. Scale bars: $50 \mu \mathrm{m}$.

Figs 31-39. Metopus fuscus, Idaho population after protargol impregnation. 31. Dorsal view showing cytopharyngeal fibers (arrowhead) and proximal end of adoral zone on the ventral side (asterisk). 32. Right ventrolateral view showing extensive fibrillar system between the adoral zone and the posterior part of cell (arrowheads) and the distal end of the perizonal stripe (arrow). 33. Detail view of the paroral membrane (white arrowhead). Paroral appears thickened proximally (black arrowhead) due to associated fibers (white arrow). Note the intensely impregnated endosymbionts (black arrows). 34. Ventral view showing the cytopyge (arrow) and the proximal right margin of the preoral dome (arrowhead). 35. Cortical granules, possibly hydrogenosomes (arrowheads) are spherical in vivo and become rod-like after protargol impregnation (cf. Fig. 16). 36. Fibrillar associates of dikinetids. The right lateral-projecting associate is longest in perizonal stripe kinety 5, inconspicuous in perizonal stripe kineties 1-4 (black asterisks) and posterior somatic kineties, and intermediate in length in dome and anterior somatic kineties. The second fibrillar associate (white arrowheads) comprises interkinetal fibrils arising from the posterior basal body of the dikinetids (cf. Fig. 17). 37. The proximal-most three or four rectangular adoral membranelles (black arrow) are comprised of four rows of basal bodies. In the central portion of the adoral zone, the right ends (black arrowheads) of 
membranelles are rectangular and taper toward the left due to inclination and loss of basal bodies (white arrows). Note the thickened proximal portion of the paroral membrane (white arrowhead).

38. Endosymbiotic bacteria (white arrowheads) envelope the macronucleus and micronucleus (black arrowhead). 39. In the distal half of the adoral zone, membranelles comprise three rows, steeply inclining in the left part (black arrowheads) and a fourth row of three basal bodies on the anterior side of the of their right ends (white arrowheads). DK3, preoral dome kinety 3; Ma, macronucleus; PS5, perizonal stripe kinety 5. Scale bars: $50 \mu \mathrm{m}(31-32,34), 10 \mu \mathrm{m}(33,36,38)$, $5 \mu \mathrm{m}(35,37,39)$.

Figs 40-45. Metopus fuscus, Idaho population in SEM. 40. Ventral view showing the ribbed undersurface of the preoral dome (asterisk), the paroral membrane (arrow), perizonal stripe cilia (white arrowhead), and elongated posterior cilia (black arrowheads). 41. Dorsal view. Arrow marks distal end of the adoral zone (cf. Figs 3, 7c, 22, 31). 42. Right view (cf. Figs. 4, 7d, 23). 43. Right ventrolateral view. 44. Ventral view. 45. Detail of proximal peristomial area showing the paroral membrane (arrowhead). Scale bars: $50 \mu \mathrm{m}$ (40-44), $25 \mu \mathrm{m}(45)$.

Figs 46-52. Newly sequenced Idaho armophorids from life. Differential interference contrast (46, 47, 49-52) and brightfield illumination (48). 46. Brachonella spiralis. Note anterior cluster of cytoplasmic granules (asterisk). 47. Brachonella galeata. 48. Metopus laminarius. 49. Metopus setosus. 50. Metopus violaceus. 51. Metopus striatus showing layer of rod-shaped extrusomes (opposing arrowheads). 52. Palmarella lata. Scale bars: $25 \mu \mathrm{m}$. 
NOTICE: this is the author's version of a work that was accepted for publication in European Journal of Protistology. Changes resulting from the publishing process, such as peer review, editing, corrections, structural formatting, and other quality control mechanisms may not be reflected in this document. Changes may have been made to this work since it was submitted for publication. A definitive version was subsequently published in European Jouranl of Protistology, (2014). DOI: 10.1016/j.ejop.2014.01.002

Figs 53-63. Metopus fuscus and its supposed synonyms in life (53a-d, 54b, 55, 56a, b, 59, 60), after mercuric chloride fixation (58a-c), and after Chatton-Lwoff silver nitrate (57a, b, 61, 63a, b) and protargol impregnation (62a, b) from the literature. 53. a. Metopus fuscus, type population, ventral view; b, c. Sketches of cell in rotation on long axis; d. Contractile vacuole in systole (from Kahl 1927, size not given). 54. Metopus fuscus, a. Fixed specimen; b. specimen with "abnormally-shaped" posterior end (from Kahl 1929). 55. Metopus fuscus, from Kahl (1931), size not given. 56. a. Metopus fuscus; b. "motion sketch”, size not given (from Kahl 1932). 57. a. Metopus fuscus; b. macro- and micronucleus (from Alekperov 1983). 58. a. Metopus fuscus Kahl, 1927, "general view”; b, c. posterior end, ventral and right view, respectively (from Jankowski 1964b, size not given). 59. Metopus fuscus (from Lundin and West 1963, size not given). 60. Metopus fuscus (from Mahajan 1977). 61. Metopus fuscus (from Alekperov and Asadullayeva 1997). 62. a. Metopus jankowskii, "general view"; b. scheme of cytoplasmic fibrils; both after protargol impregnation (from Dragesco 1968). 63. a. Metopus fuscoides; b. macro- and micronucleus (from Alekperov 1984). Scale bars: $50 \mu \mathrm{m}$.

Fig. 64. Armophorean $18 \mathrm{~S}$ rDNA phylogeny. Sequences from the present study are in bold. Species marked with an asterisk are to be described in future publications (see Figs 46-52). Nonbold species sequences are from GenBank. GenBank accession numbers follow each species name. BI, Bayesian inference. ML, Maximum likelihood. Scale bar: number of substitutions per nucleotide site. 
Figs 1-9

NOTICE: this is the author's version of a work that was accepted for publication in European Journal of Protistology. Changes resulting from the publishing process, such as peer review, editing, corrections, structural formatting, and other quality control mechanisms may not be reflected in this document. Changes may have been made to this work since it was submitted for publication. A definitive version was subsequently published in European Jouranl of Protistology, (2014). DOI: 10.1016/ j.ejop.2014.01.002

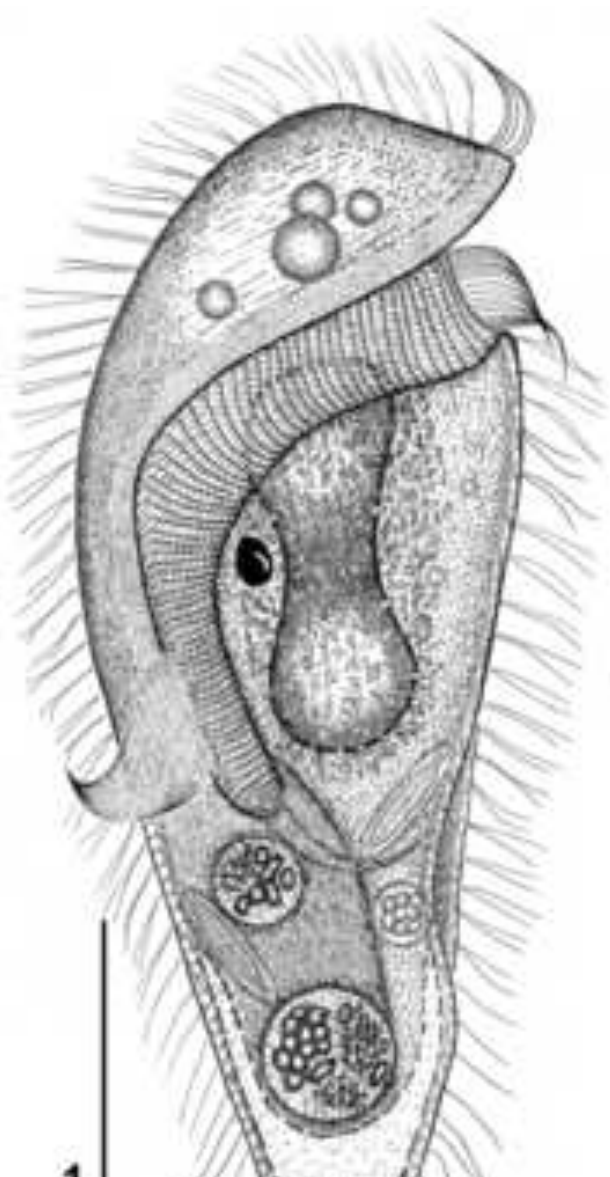

11
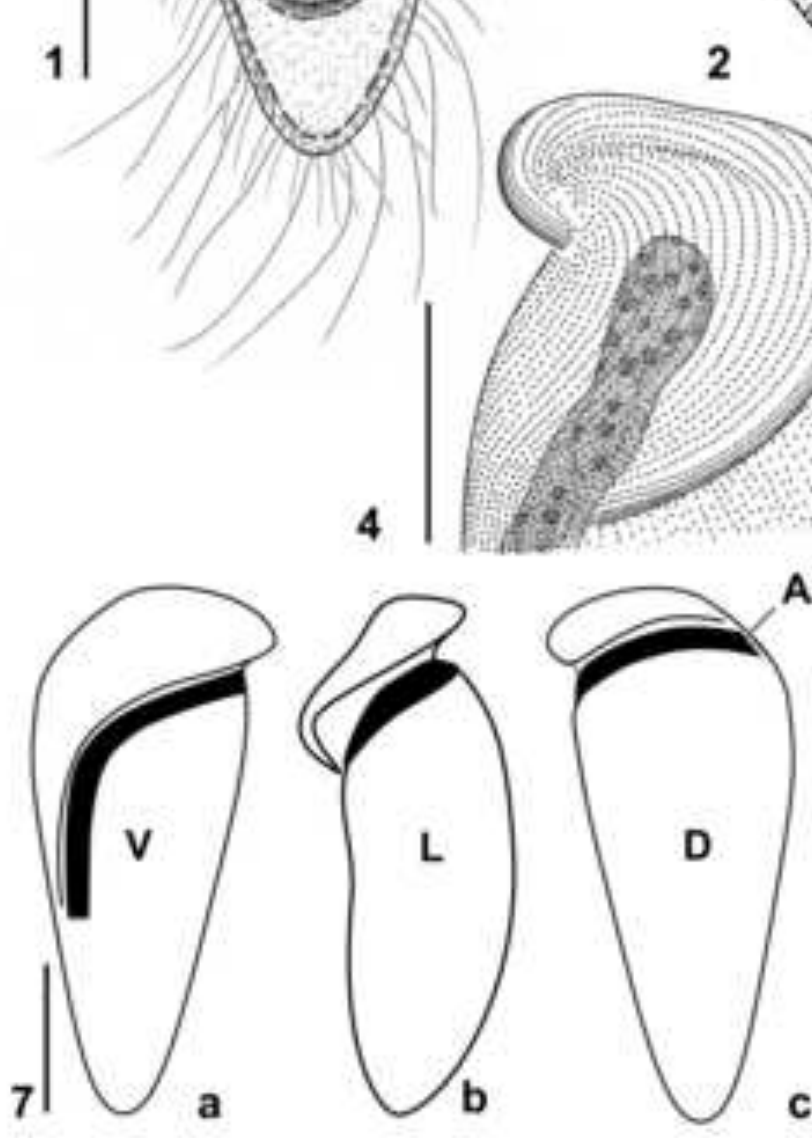

AZM
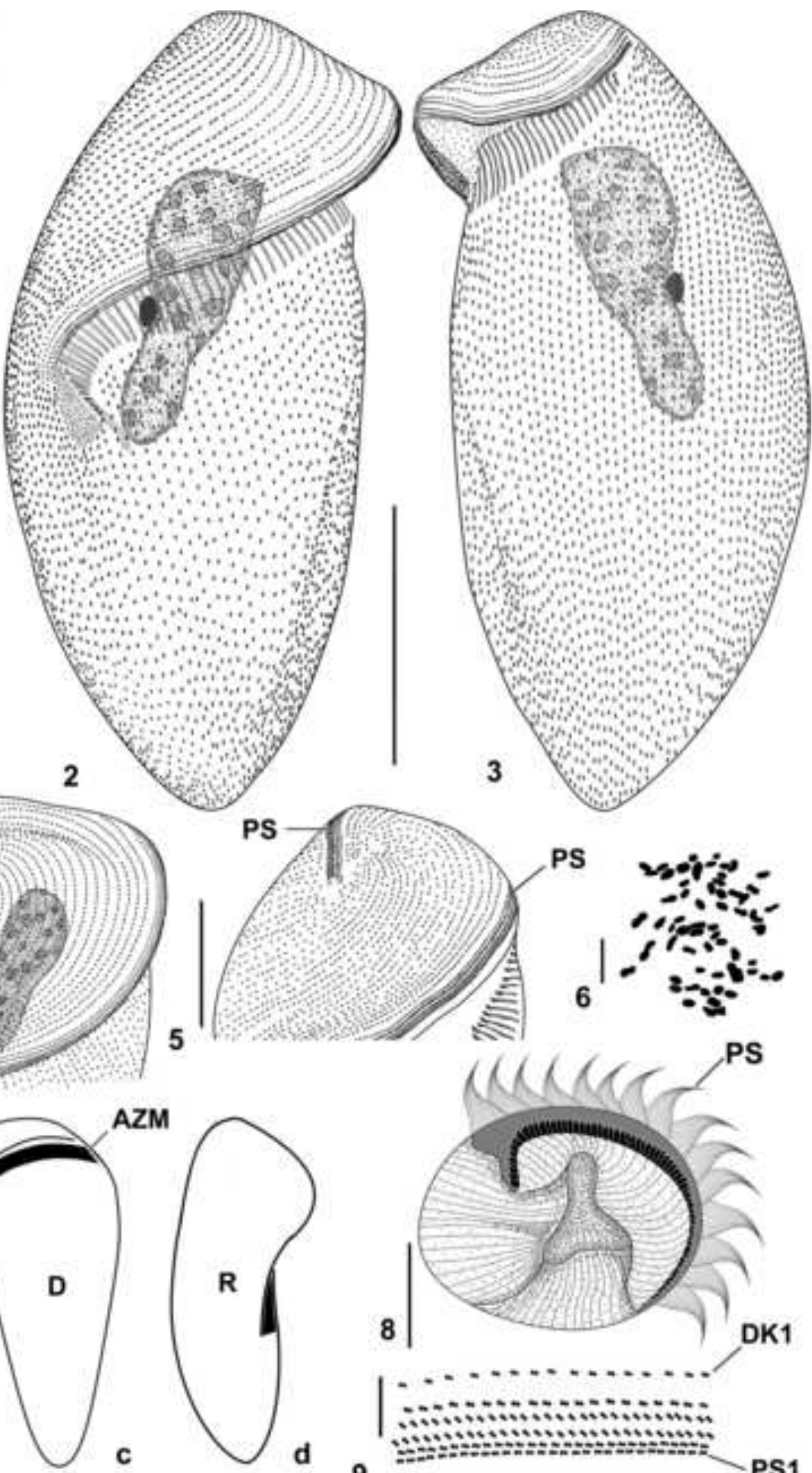

5

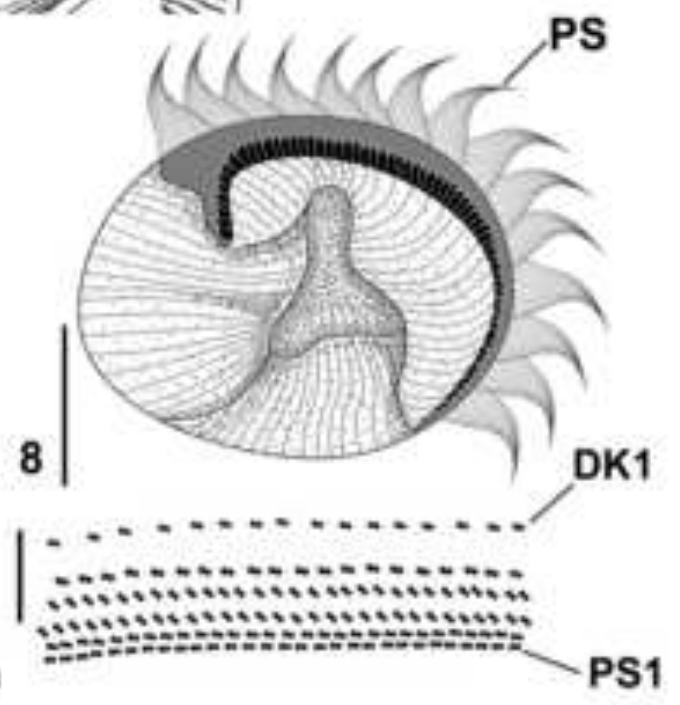


Figure 10-20
$\begin{aligned} & \text { NOTICE: this is the author's version of a work that was accepted for publication in European Journal of Protistology. Changes resulting from the publishing process, such as peer review, editing, } \\ & \text { corrections, structural formatting, and other quality control mechanisms may not be reflected in this document. Changes may have been made to this work since it was submitted for publication. A }\end{aligned}$

Figure 10-20
$\begin{aligned} & \text { NOTICE: this is the author's version of a work that was accepted for publication in European Journal of Protistology. Changes resulting from the publishing process, such as peer review, editing, } \\ & \text { corrections, structural formatting, and other quality control mechanisms may not be reflected in this document. Changes may have been made to this work since it was submitted for publication. A }\end{aligned}$ corrections, structural formatting, and other quality control mechanisms may not be reflected in this document. Changes m
definitive version was subsequently published in European Jouranl of Protistology, (2014). DOI: 10.1016/j.ejop.2014.01.002
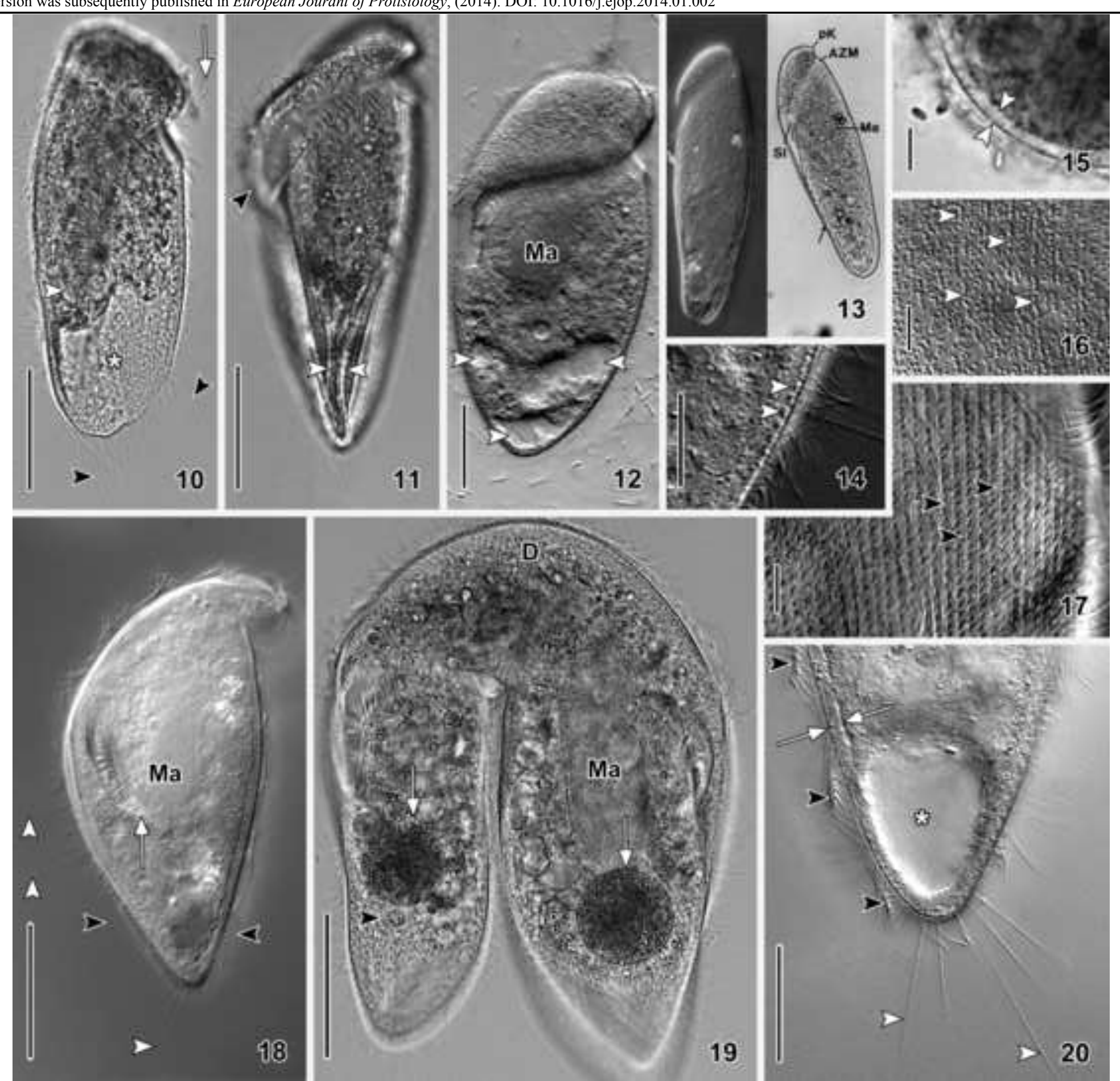

$\rightarrow f^{2}=$

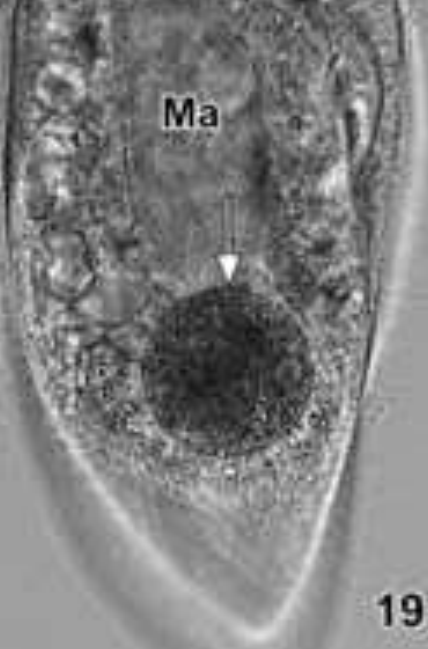

19

$\begin{array}{r}20 \\ \hline\end{array}$ 
NOTICE: this is the author's version of a work that was accepted for publication in European Journal of Protistology. Changes resulting from the publishing process, such as peer review, editing, corrections, structural formatting, and other quality control mechanisms may not be reflected in this document. Changes may have been made to this work since it was submitted for publication. A definitive version was subsequently published in European Jouranl of Protistology, (2014). DOI: 10.1016/ j.ejop.2014.01.002

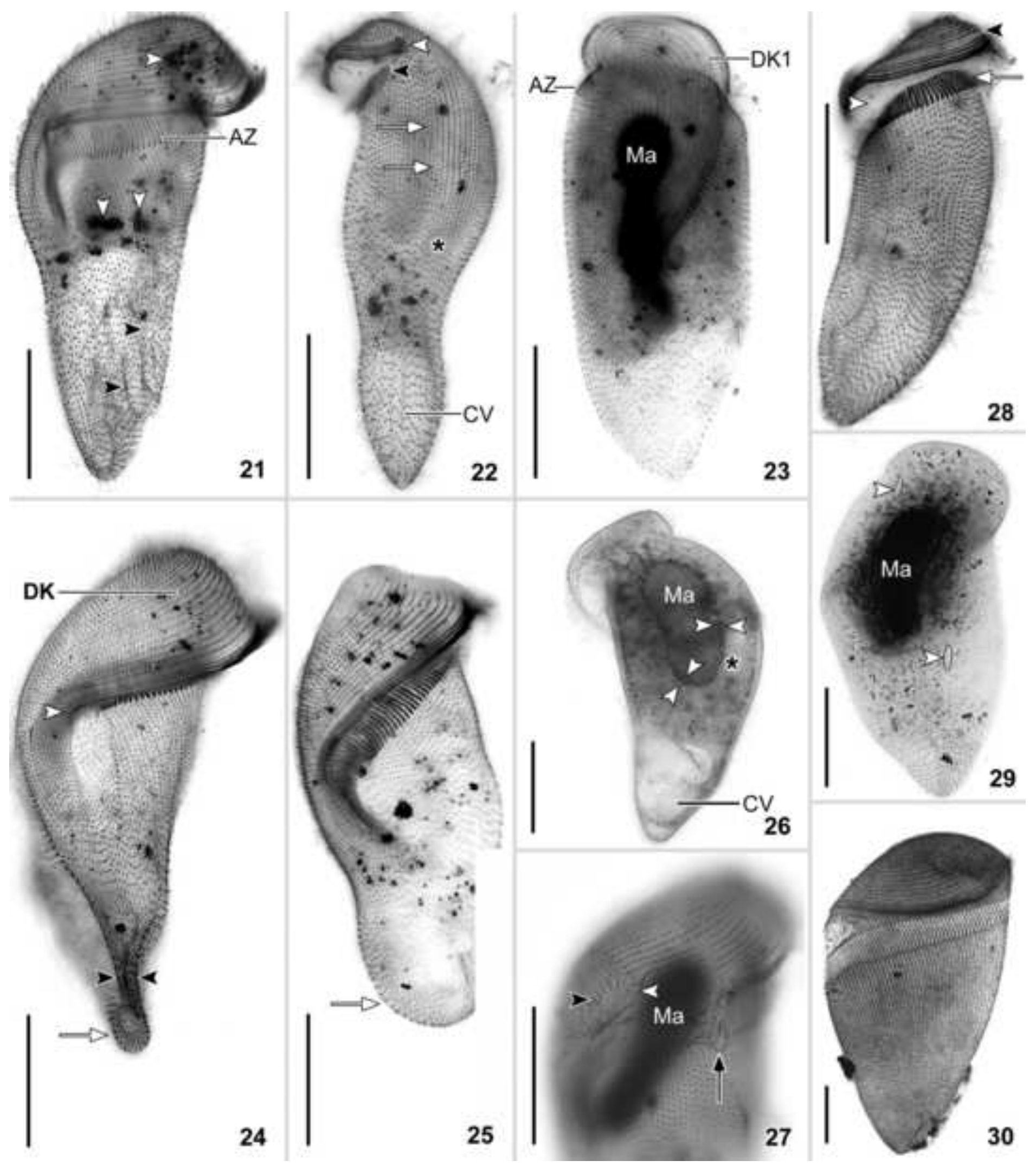




\section{Figs $31-39$}

NOTICE: this is the author's version of a work that was accepted for publication in European Journal of Protistology. Changes resulting from the publishing process, such as peer review, editing, corrections, structural formatting, and other quality control mechanisms may not be reflected in this document. Changes may have been made to this work since it was submitted for publication. A definitive version was subsequently published in European Jouranl of Protistology, (2014). DOI: 10.1016/ j.ejop.2014.01.002
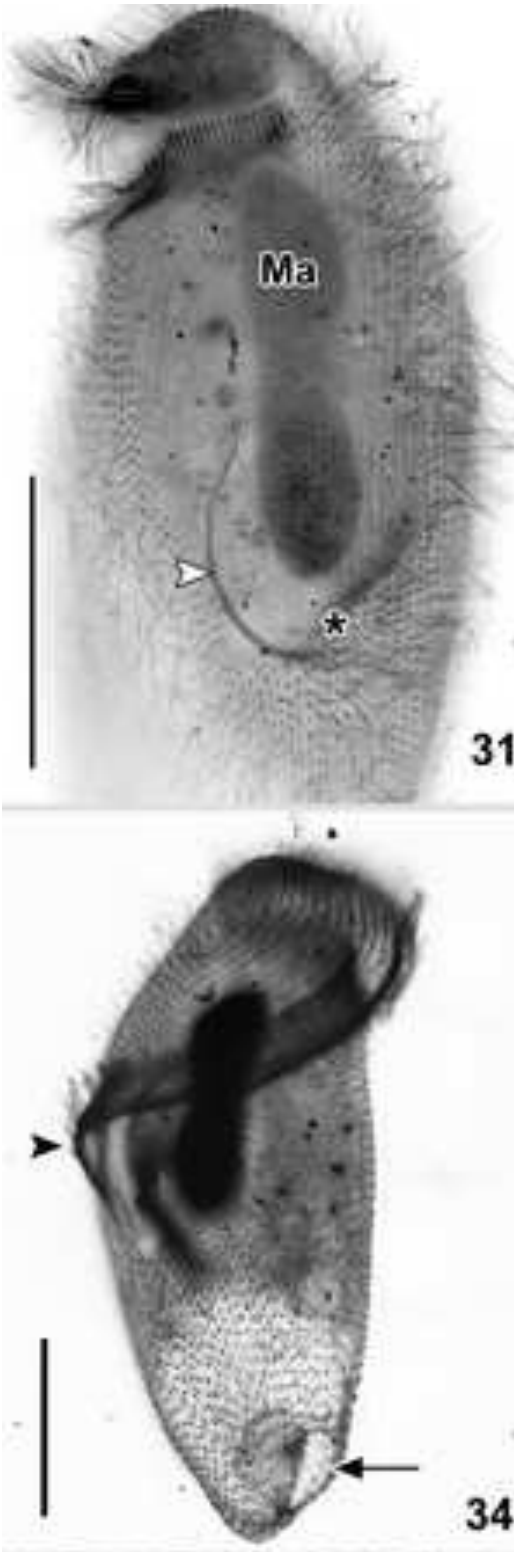

31

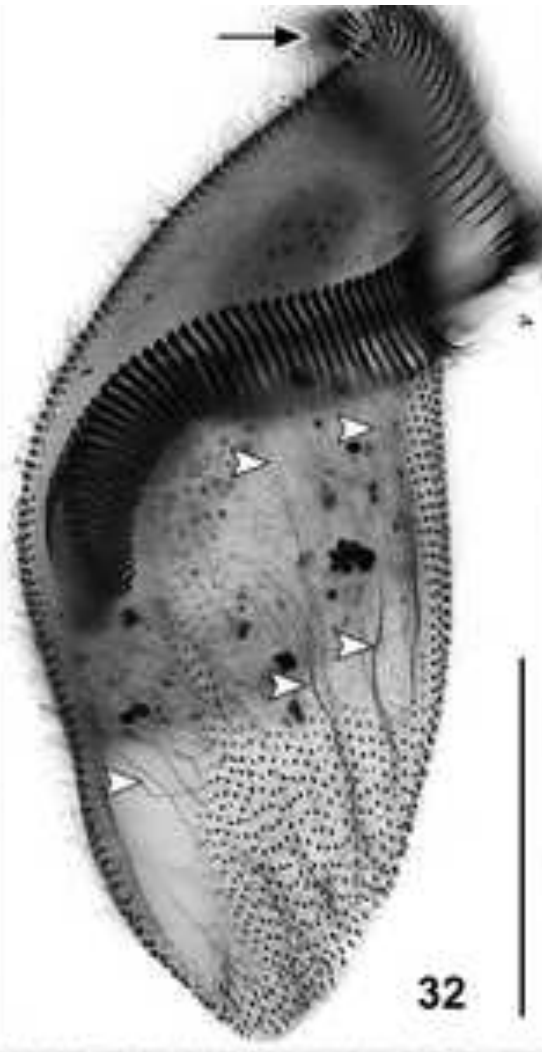

34

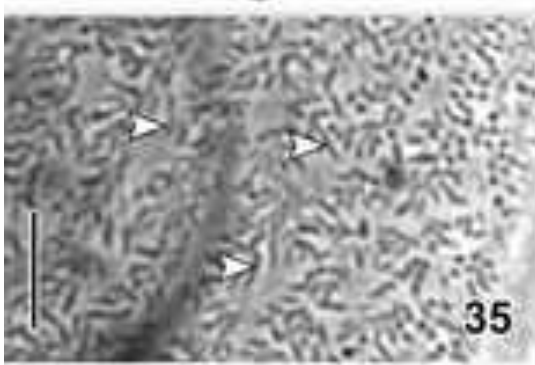

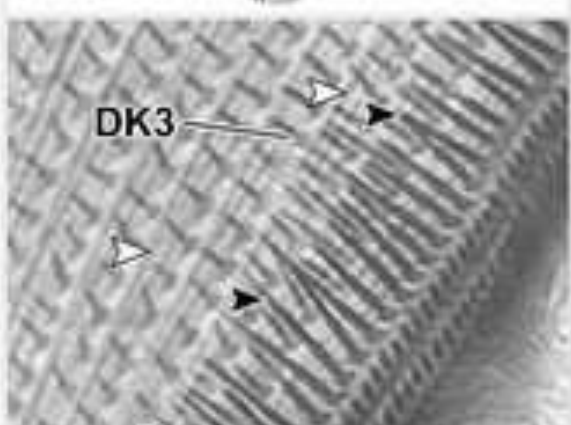
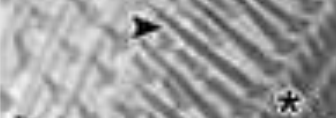
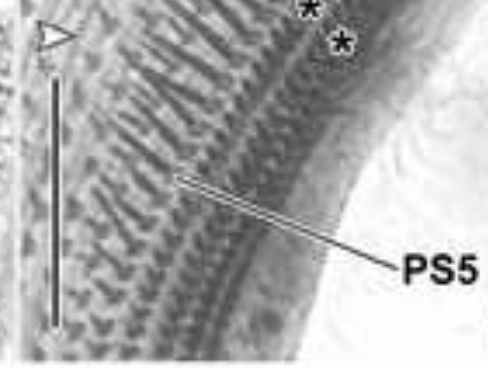

PS5

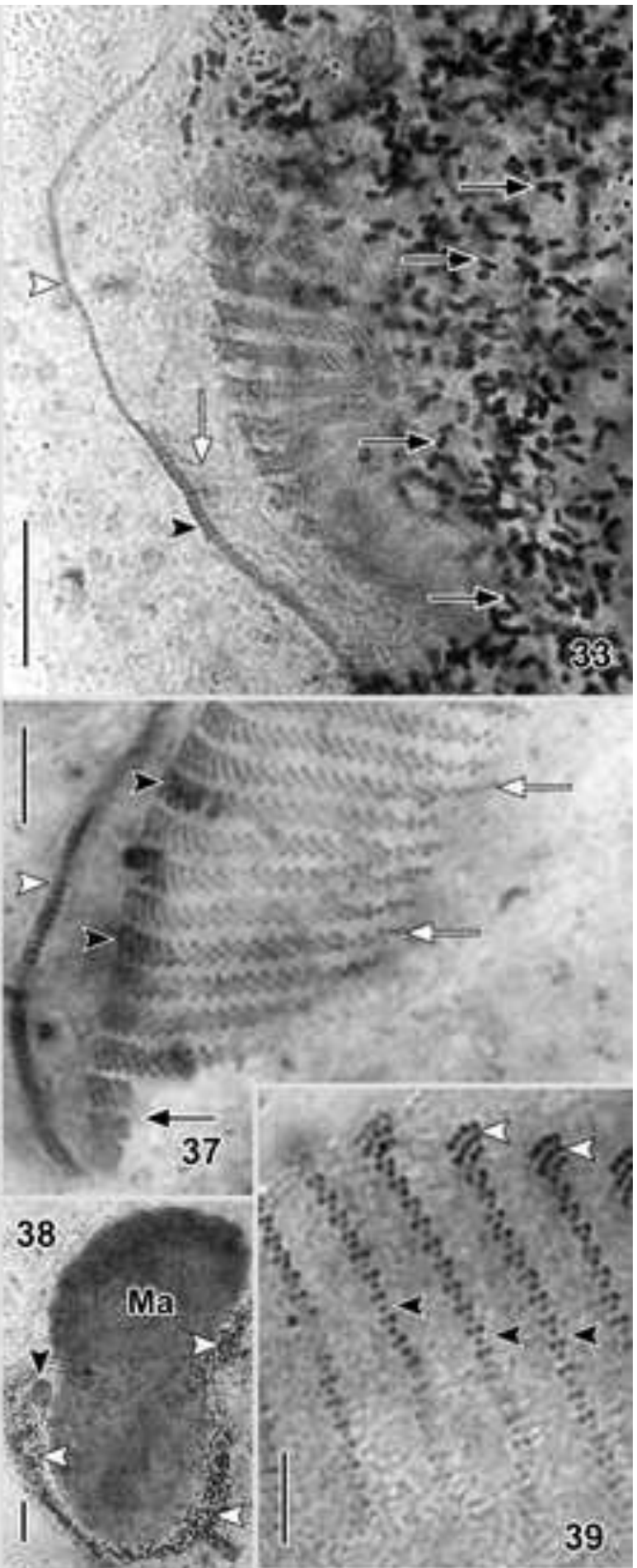


NOTICE: this is the author's version of a work that was accepted for publication in European Journal of Protistology. Changes resulting from the publishing process, such as peer review, editing, corrections, structural formatting, and other quality control mechanisms may not be reflected in this document. Changes may have been made to this work since it was submitted for publication. A definitive version was subsequently published in European Jouranl of Protistology, (2014). DOI: 10.1016/ j.ejop.2014.01.002
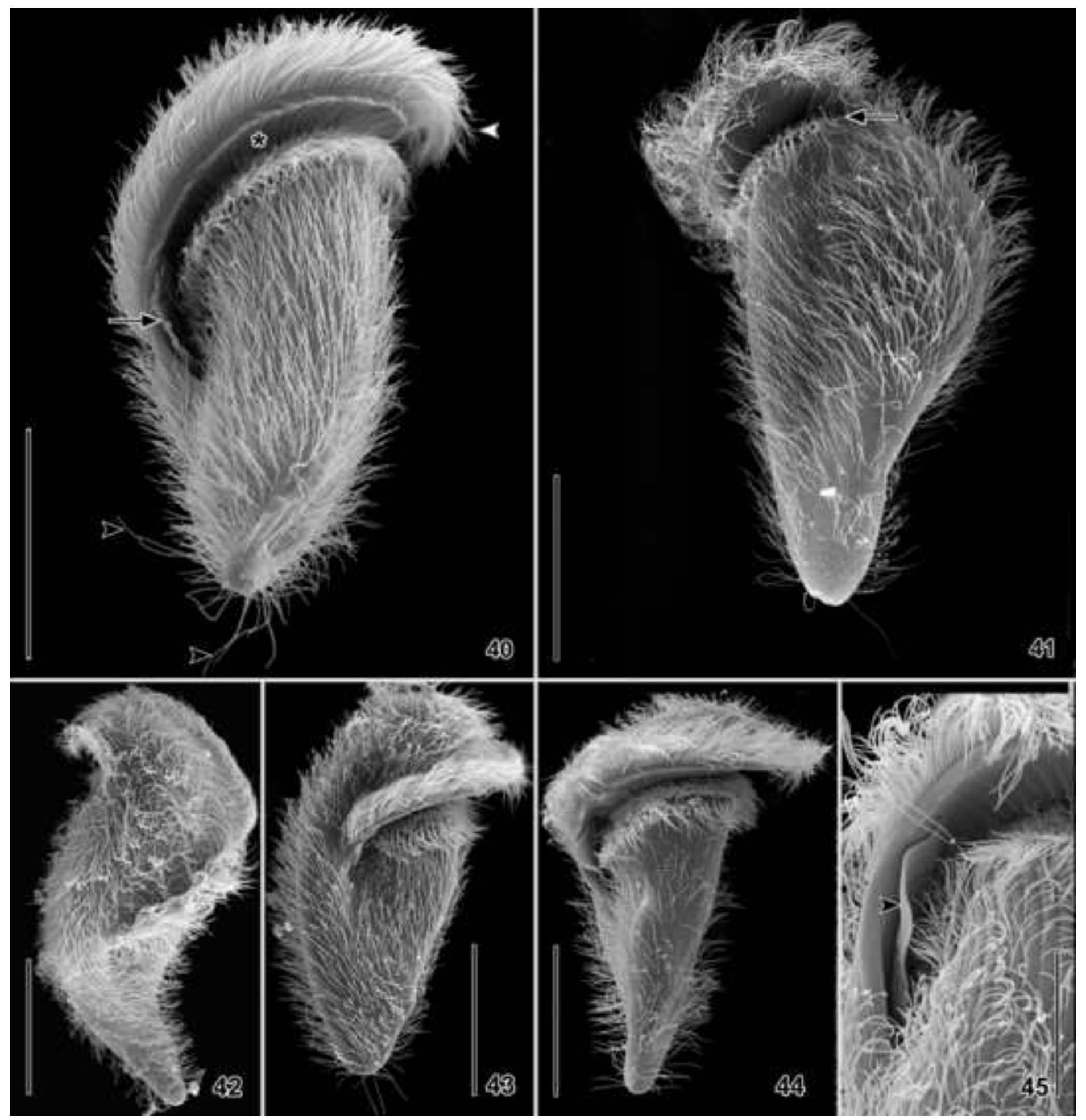


\section{Figs $46-52$}

NOTICE: this is the author's version of a work that was accepted for publication in European Journal of Protistology. Changes resulting from the publishing process, such as peer review, editing, corrections, structural formatting, and other quality control mechanisms may not be reflected in this document. Changes may have been made to this work since it was submitted for publication. A definitive version was subsequently published in European Jouranl of Protistology, (2014). DOI: 10.1016/ j.ejop.2014.01.002

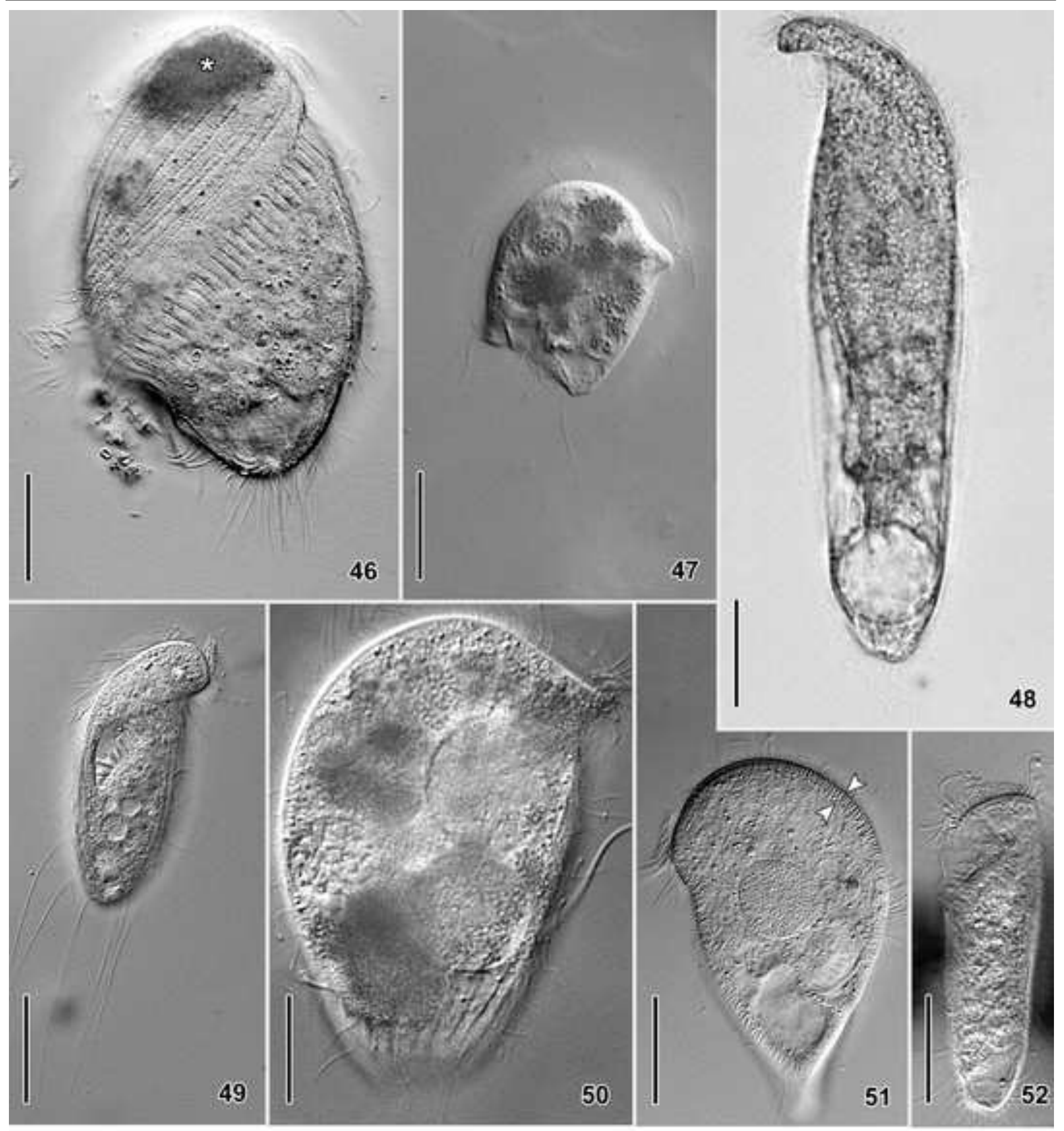




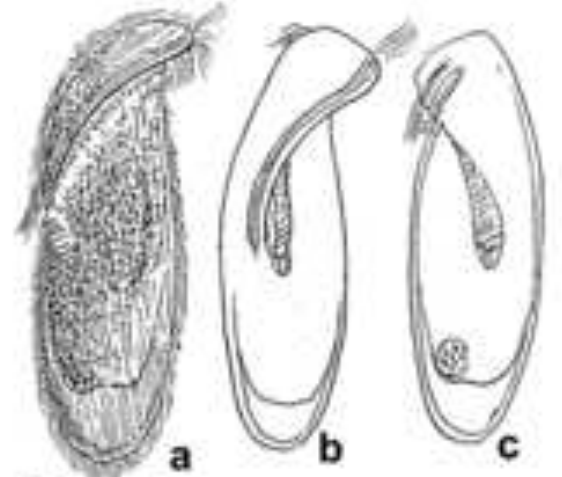

53

58

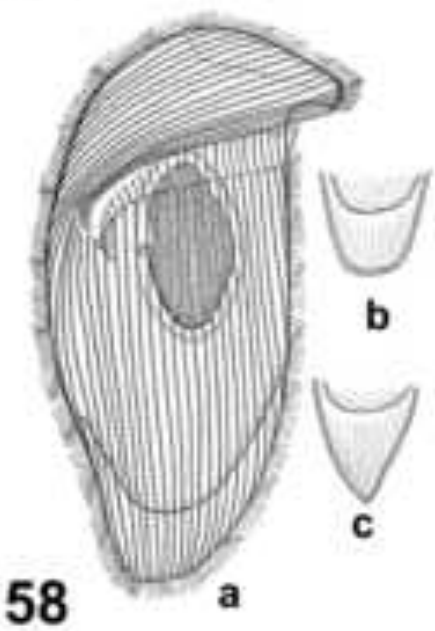

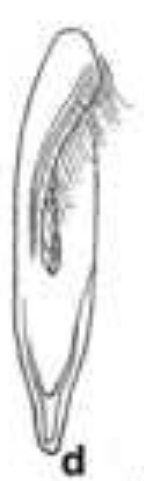

54 a
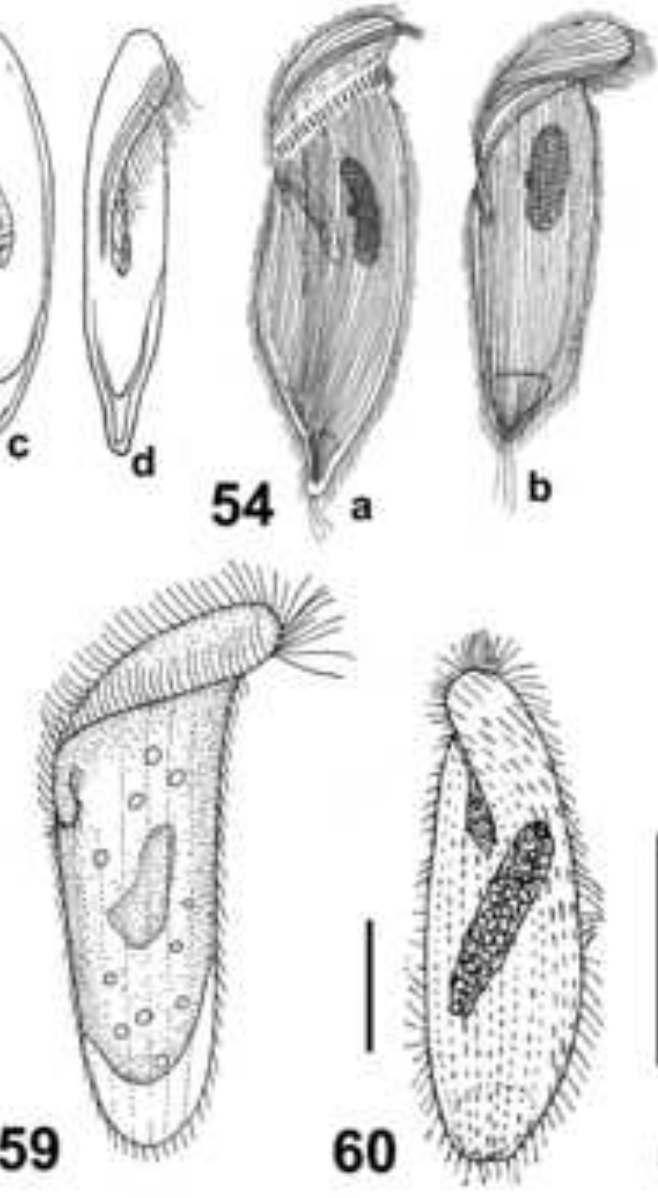

55

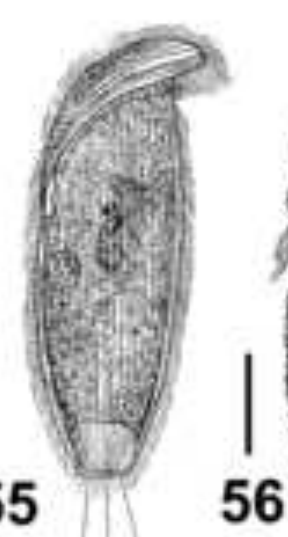

56

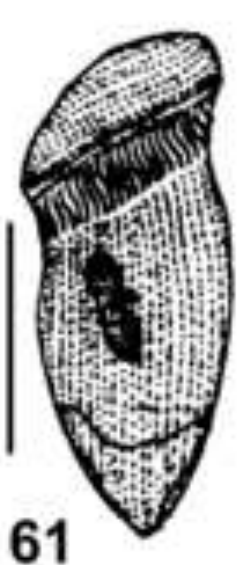

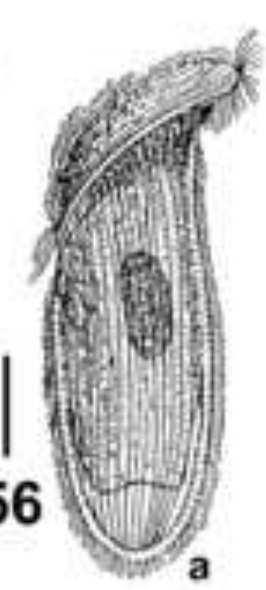
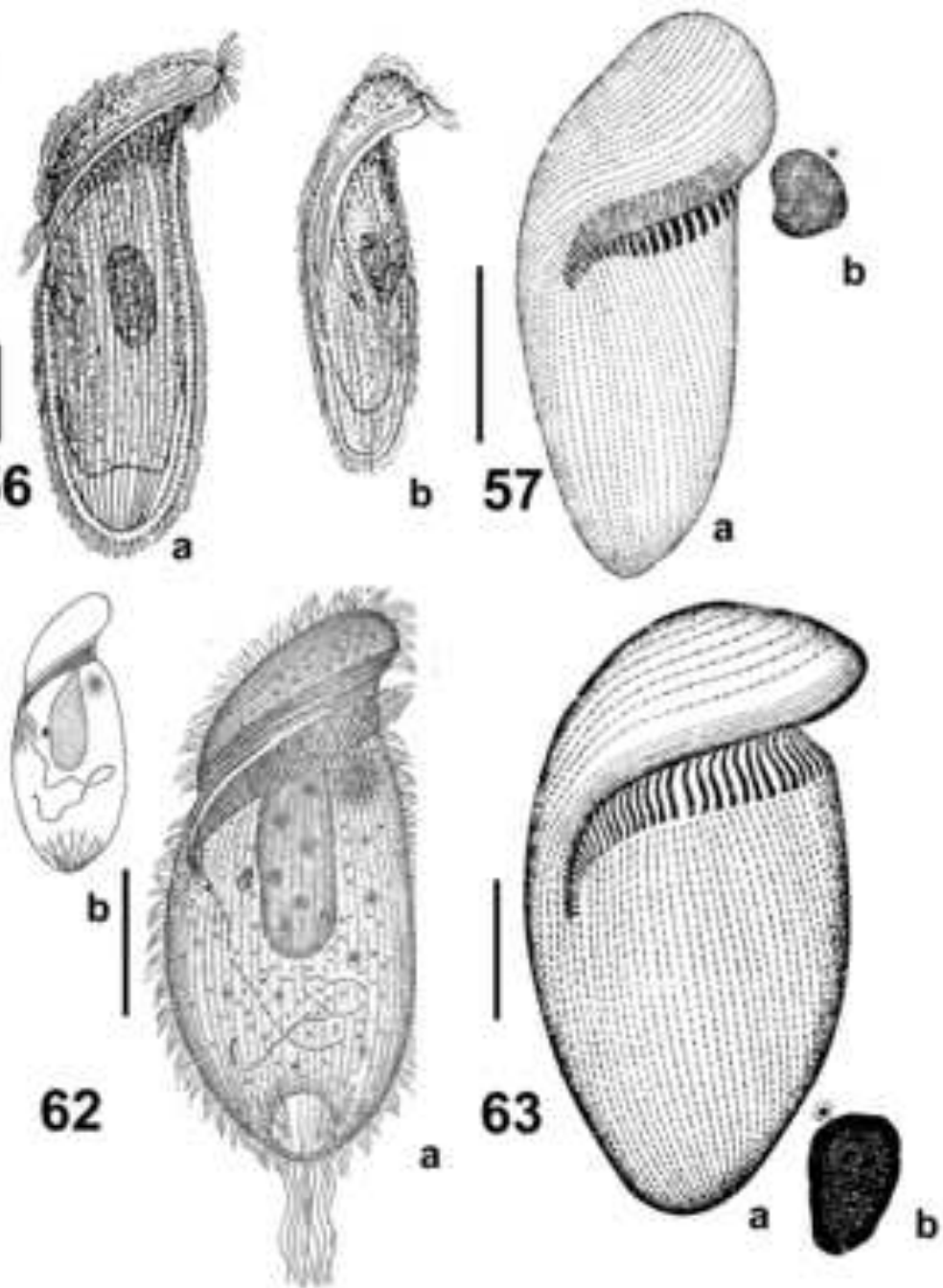
NOTICE: this is the author's version of a work that was accepted for publication in European Journal of Protistology. Changes resulting from the publishing process, such as peer review, editing, corrections, structural formatting, and other quality control mechanisms may not be reflected in this document. Changes may have been made to this work since it was submitted for publication. A definitive version was subsequently published in European Jouranl of Protistology, (2014). DOI: 10.1016/j.ejop.2014.01.002

\section{$\mathrm{BI} / \mathrm{ML}$}

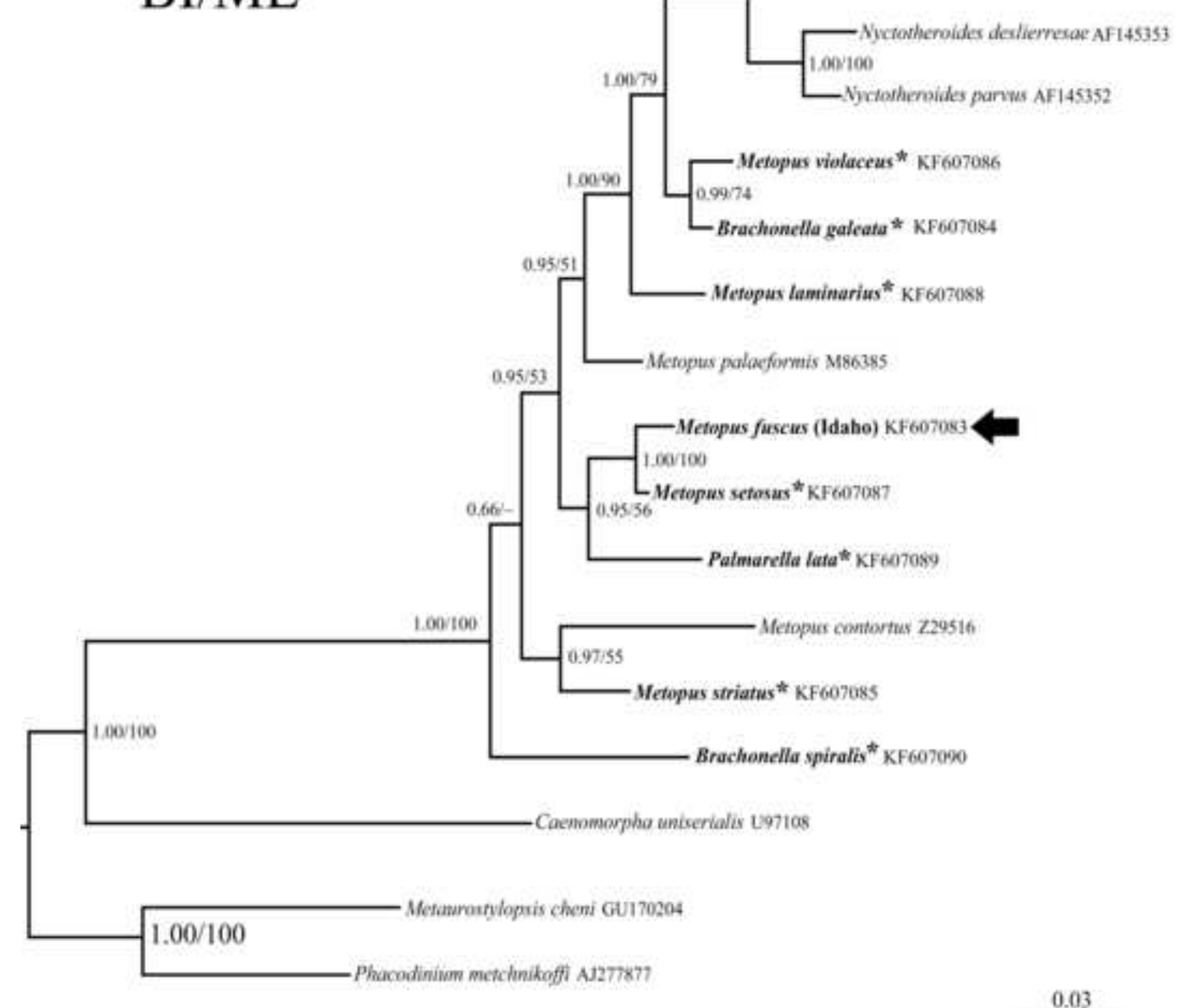



DOI: $10.1016 /$ j.ejop.2014.01.002

Table 1. Morphometric data from Metopus fuscus.

\begin{tabular}{lrrrrrrr}
\hline Characteristic $^{\mathrm{a}}$ & Mean & \multicolumn{1}{c}{ M } & SD & CV & Min & Max & n \\
\hline Body, length (A) & 165.8 & 167.0 & 15.55 & 9.4 & 138.0 & 195.0 & 27 \\
Body, total width $^{\mathrm{b}}$ & 73.4 & 71.0 & 10.46 & 14.2 & 57.0 & 99.0 & 27 \\
Body, width posterior to preoral dome & 62.0 & 62.0 & 12.28 & 19.8 & 44.0 & 85.0 & 27 \\
Body, length:total width ratio & 2.3 & 2.3 & 0.19 & 8.2 & 2.0 & 2.7 & 27 \\
Body, length/width ratio posterior to preoral dome, & 2.8 & 2.8 & 0.38 & 13.8 & 2.0 & 3.6 & 27
\end{tabular}
ratio

Anterior body end to proximal end of perizonal stripe, distance (B)

$\mathrm{B}: \mathrm{A}$, ratio

Anterior body end to proximal end of adoral zone, distance (C)

C:A, ratio

Macronucleus, length

Macronucleus, anterior diameter

Macronucleus, posterior diameter

Macronucleus, central diameter

Anterior body end to posterior end of macronucleus, distance

Micronucleus, length

Micronucleus, width

Anterior body end to distal end of paroral, distance

Adoral membranelles, number

Perizonal ciliary stripe rows, number $\begin{array}{lllllll}80.9 & 80.0 & 13.23 & 16.4 & 45.0 & 106.0 & 27\end{array}$

$\begin{array}{lllllll}0.5 & 0.5 & 0.06 & 13.4 & 0.3 & 0.6 & 27\end{array}$

$\begin{array}{lllllll}99.0 & 97.0 & 11.46 & 11.5 & 81.0 & 123.0 & 27\end{array}$

$\begin{array}{lllllll}0.6 & 0.6 & 0.06 & 10.3 & 0.5 & 0.7 & 27\end{array}$

$\begin{array}{lllllll}58.3 & 57.4 & 8.90 & 15.2 & 45.7 & 80.0 & 27\end{array}$

$\begin{array}{lllllll}19.2 & 18.9 & 1.93 & 10.1 & 16.2 & 23.8 & 27\end{array}$

$\begin{array}{lllllll}16.7 & 17.0 & 2.92 & 17.4 & 9.7 & 21.7 & 27\end{array}$

$\begin{array}{lllllll}14.0 & 14.5 & 3.44 & 24.6 & 8.1 & 21.0 & 27\end{array}$

$\begin{array}{lllllll}90.5 & 88.0 & 9.90 & 10.9 & 76.0 & 111.0 & 27\end{array}$

$\begin{array}{lllllll}5.5 & 5.5 & 0.67 & 12.2 & 4.2 & 7.3 & 27\end{array}$

$\begin{array}{lllllll}3.6 & 3.7 & 0.46 & 12.6 & 2.7 & 4.5 & 26\end{array}$

$\begin{array}{lllllll}63.6 & 60.0 & 11.66 & 18.3 & 42.0 & 92.0 & 27\end{array}$

$\begin{array}{lllllll}84.9 & 83.5 & 7.38 & 8.7 & 74.0 & 103.0 & 26\end{array}$

$\begin{array}{lllllll}5.0 & 5.0 & 0.00 & 0.0 & 5.0 & 5.0 & 27\end{array}$ 
NOTICE: this is the author's version of a work that was accepted for publication in European Journal of Protistology. Changes resulting from the publishing process, such as peer review, editing, corrections, structural formatting, and other quality control mechanisms may not be reflected in this document. Changes may have been made to this work since it was submitted for publication. A definitive version was subsequently published in European Jouranl of Protistology, (2014). DOI: $10.1016 /$ j.ejop.2014.01.002

Preoral dome kineties, number

Somatic kineties, number ${ }^{\mathrm{c}}$

${ }^{a}$ Data based on randomly selected formalin-fixed protargol impregnated specimens. All measurements in $\mu \mathrm{m} . \mathrm{CV}$, coefficient of variation (\%); M, median; Max, maximum; Mean, arithmetic mean; Min, minimum; n, number of individuals investigated; POM, paroral membrane; SD, standard deviation

${ }^{\mathrm{b}}$ Width including margins of preoral dome.

${ }^{\mathrm{c}}$ Number includes dome kineties. 
NOTICE: this is the author's version of a work that was accepted for publication in European Journal of Protistology. Changes resulting from the publishing process, such as peer review, editing, corrections, structural formatting, and other quality control mechanisms may not be reflected in this document. Changes may have been made to this work since it was submitted for publication. A definitive version was subsequently published in European Jouranl of Protistology, (2014). DOI: $10.1016 /$ j.ejop.2014.01.002

Table 2. Analyses of topological constraints.

\begin{tabular}{lcc}
\hline Constraint $^{\mathrm{a}}$ & -Log likelihood & AU test (p) \\
\hline Unconstrained & 6187.22 & 0.52 \\
Metopus spp. & 6257.42 & 0.001 \\
Brachonella spp. & 6232.11 & 0.001 \\
& & \\
M.fuscus + M. setosus + P.lata & 6187.22 & 0.48 \\
Metopus spp. + Brachonella galeata + Palmarella lata & 6228.22 & $<0.001$ \\
& & \\
Metopus spp. + Caenomorpha uniserialis & 6299.41 & $<0.001$ \\
& & \\
\hline
\end{tabular}

${ }^{a}$ Contraint $=$ monophyly of group

AU - approximately unbiased test 